\title{
Fenton Technology for Wastewater Treatment: Dares and Trends
}

\author{
Djamel Ghernaout ${ }^{1,2 *}$, Noureddine Elboughdiri1 ${ }^{1,3}$, Saad Ghareba ${ }^{1,4}$ \\ ${ }^{1}$ Chemical Engineering Department, College of Engineering, University of Ha'il, Ha'il, Saudi Arabia \\ ${ }^{2}$ Chemical Engineering Department, Faculty of Engineering, University of Blida, Blida, Algeria \\ ${ }^{3}$ Département de Génie Chimique de Procédés, Laboratoire Modélisation, Analyse, et Commande des Systèmes, Ecole Nationale \\ d'Ingénieurs de Gabès (ENIG), Gabès, Tunisia \\ ${ }^{4}$ Department of Chemical and Petroleum Engineering, El Mergib University, Alkhums, Libya \\ Email: *djamel_andalus@hotmail.com
}

How to cite this paper: Ghernaout, D., Elboughdiri, N. and Ghareba, S. (2020) Fenton Technology for Wastewater Treatment: Dares and Trends. Open Access Library Journal, 7: e6045.

https://doi.org/10.4236/oalib.1106045

Received: January 2, 2020

Accepted: January 14, 2020

Published: January 17, 2020

Copyright $\odot 2020$ by author(s) and Open Access Library Inc.

This work is licensed under the Creative Commons Attribution International License (CC BY 4.0).

http://creativecommons.org/licenses/by/4.0/

\begin{abstract}
Fenton reaction remains an efficient technique for decomposing recalcitrant organic contaminants. Nevertheless, traditional Fenton response has many limitations like the necessity of acidic $\mathrm{pH}$ circumstance, the formation of iron sludge and the need for elevated chemical introductions. Procedures like heterogeneous Fenton, fluidized-bed Fenton, employment of chelating products and in situ formations of Fenton's reagent have been examined as likely solutions to such drawbacks. Bello et al. [1] presented an excellent discussion of the restrictions of Fenton reaction and the fresh manners for dealing with them and this work focuses on its main findings. The heterogeneous Fenton method stays the most largely examined thanks to the expansion achieved in catalysis. The fluidized-bed Fenton method has the capacity to diminish sludge formation and ameliorate technology efficiency. Chelating chemicals are employed to performing homogeneous Fenton at circumneutral $\mathrm{pH}$, even if the potentially decisive impact of many chelating products remains a source of worry. In situ formation of Fenton's reagent via bio-electrochemical technique (bio-electro-Fenton) seems to be a likely manner to diminish the price related to Fenton's reagent. Despite the progress registered in the Fenton technologies, the classical process, and its ameliorated versions, membranes processes remain fundamental for secure wastewater treatment. As sure barriers towards pollution dispersal, processes such as nanofiltration should be coupled to Fenton techniques.
\end{abstract}

\section{Subject Areas}

Environmental Sciences

\section{Keywords}

Wastewater Treatment, Fenton Process, Pharmaceuticals and Personal Care 
Products (PPCPs), Bio-Electro-Fenton, Electro-Fenton Process, Fluidized-Bed Fenton

\section{Introduction}

There is an increasing endeavor to expand efficient techniques able of eliminating recalcitrant pollutants from wastewaters [1] [2]. Several organic contaminants, like pharmaceuticals and personal care products (PPCPs), are recalcitrant to the traditional wastewater treatment techniques [3] [4] [5]. Numerous investigations have proved the existence of diverse recalcitrant and emerging contaminants in the effluents of traditional wastewater treatment plants (WWTPs) [6] [7] [8]. Such contaminants might restrict the possible reuse of the treated wastewater and constitute dangers to public health and nature [9] [10] [11] [12] [13]. For instance, chronic toxicity and endocrine disruption have been related to the existence of even a low level of PPCP [14].

Because of the imperfections of traditional wastewater treatment techniques in dealing with recalcitrant contaminants [15] [16] [17] [18], attempts have been escalated to discover substitutional techniques. Even if physicochemical processes like adsorption might reduce recalcitrant contaminants from wastewater, they are mainly separation techniques and additional remediation may be needed [19] [20] [21]. Biodegrading recalcitrant contaminants are frequently slow and mainly transform the organic contaminants into several intermediates, which may therewith cumulate in nature [22] [23]. Consequently, efficient remediation necessitates the total mineralization of such recalcitrant contaminants [1] [24] [25]. This may be attained by advanced oxidation processes (AOPs) [26] [27] [28], which are capable of efficaciously oxidizing organic chemicals.

During AOPs, hydroxyl radicals $\left({ }^{\circ} \mathrm{OH}\right)$ are produced through a series of methods [29]. The ${ }^{\circ} \mathrm{OH}$ (oxidation potential $=2.8 \mathrm{eV}$ ) could enter in mutual actions with the contaminants (rate constant: $109 \mathrm{M}^{-1} \cdot \mathrm{s}^{-1}$ ), oxidizing them to simpler intermediates and probably to $\mathrm{CO}_{2}$ and $\mathrm{H}_{2} \mathrm{O}$ [30]. During the last decade, AOPs have attracted huge attention. They are viewed as the preferable techniques for decomposing recalcitrant contaminants [31]. Usually, AOPs are categorized following the procedure of producing the ${ }^{\circ} \mathrm{OH}$. Such procedures comprise Fenton oxidation [30], photocatalysis [32], UV-founded techniques, ozonation [29], sonolysis [33] and electrochemical oxidation [1] [34].

Fenton oxidation is an efficacious AOP and implies a catalytic degradation of hydrogen peroxide $\left(\mathrm{H}_{2} \mathrm{O}_{2}\right)$ by ferrous iron $\left(\mathrm{Fe}^{2+}\right)$ to form ${ }^{\circ} \mathrm{OH}$ following Equation (1) [18]. The produced ${ }^{\circ} \mathrm{OH}$ after that oxidizes the organic contaminant (Equation (2)). The initial step of the technique is a rapid degradation of $\mathrm{H}_{2} \mathrm{O}_{2}$ by $\mathrm{Fe}^{2+}$ [35], which forms a significant quantity of ${ }^{\circ} \mathrm{OH}$ and transform $\mathrm{Fe}^{2+}$ to $\mathrm{Fe}^{3+}$ [36] [37] (Equation (3)) [1]. Even if Fenton oxidation is mostly defined in such straightforward stages, the technology is considerably more combined since it implicates numerous additional reactions. Usually, such techniques may be 
largely classified into initiation, propagation and termination reactions [38].

$$
\begin{gathered}
\mathrm{H}_{2} \mathrm{O}_{2}+\mathrm{Fe}^{2+} \rightarrow \mathrm{Fe}^{3+}+{ }^{\cdot} \mathrm{OH}+\mathrm{OH}^{-} \\
\cdot \mathrm{OH}+\text { Organic } \rightarrow \text { Products } \\
\cdot \mathrm{OH}+\mathrm{Fe}^{2+} \rightarrow \mathrm{Fe}^{3+}+\mathrm{OH}^{-}
\end{gathered}
$$

The ${ }^{\circ} \mathrm{OH}$ may enter in mutual reactions with organic matter and/or Fenton catalyst through either of three routes: 1) hydroxyl addition, 2) hydrogen abstraction or 3) electron transfer [39]. Hydroxyl addition happens with organic chemicals possessing aromatic systems or carbon-carbon multiple bonds (Equation (4)). Hydrogen abstraction takes place with unsaturated organic chemicals (Equation (5)) while electron transfer happens if ${ }^{\circ} \mathrm{OH}$ interacts with inorganic ions (Equation (6)) [1].

$$
\begin{gathered}
\cdot \mathrm{OH}+\mathrm{R} \rightarrow \mathrm{R}(\mathrm{OH}) \\
\cdot \mathrm{OH}+\mathrm{RH} \rightarrow \mathrm{R}+\mathrm{H}_{2} \mathrm{O} \\
\mathrm{Fe}^{2+}+{ }^{\bullet} \mathrm{OH} \rightarrow \mathrm{Fe}^{3+}+\mathrm{OH}^{-}
\end{gathered}
$$

The most important benefits of Fenton process are the simplicity of the method and the efficient decomposition of contaminants. Further, both $\mathrm{Fe}^{2+}$ [40] and $\mathrm{H}_{2} \mathrm{O}_{2}$ are easily obtainable, simple to manipulate and environmentally harmless. Fenton oxidation has been largely tried for dealing with diverse wastewater streams like textiles [41] [42], pharmaceuticals [43] [44], olive mill [45] [46], leachate [47], agrochemicals [48] [49] and other recalcitrant pollutants. Moreover, Fenton oxidation was presented as an environmentally secure choice for sludge conditioning and treatment [50]. For instance, researchers [51] tried Fenton process for the conditioning of sewage sludge and examined the contribution of iron [52] species and $\mathrm{pH}$ optimization. The Fenton oxidation transformed most of the sludge-bound water to free water, improving its dewater-capacity. The process was more assisted by the coagulating impact of $\mathrm{Fe}^{3+}[1]$ [53] [54] [55] [56].

Fenton process is influenced by diverse running factors, comprising the level and ratio of Fenton's reagent $\left(\mathrm{H}_{2} \mathrm{O}_{2}\right.$ and $\left.\mathrm{Fe}^{2+}\right)$, solution $\mathrm{pH}$, time, temperature, contaminant concentration and the type of the reaction matrix [1]. Nevertheless, Fenton's reagent and $\mathrm{pH}$ are frequently viewed as the most crucial factors. The level of $\mathrm{H}_{2} \mathrm{O}_{2}$ dictates the possible ${ }^{\circ} \mathrm{OH}$ that will be formed in the method. This implies that the more $\mathrm{H}_{2} \mathrm{O}_{2}$, the more ${ }^{\circ} \mathrm{OH}$ will be possibly produced, following the level of $\mathrm{Fe}^{2+}$ and different working circumstances. Nevertheless, a surplus level of $\mathrm{H}_{2} \mathrm{O}_{2}$ may conduct to a scavenging impact where the $\mathrm{H}_{2} \mathrm{O}_{2}$ reacts with the ${ }^{\circ} \mathrm{OH}$, transforming it to the less reactive $\mathrm{HO}_{2}{ }^{\cdot}$ [21]. Further, $\mathrm{Fe}^{2+}$ works as a catalyst for the degradation of $\mathrm{H}_{2} \mathrm{O}_{2}$. Consequently, augmenting the level of $\mathrm{Fe}^{2+}$ may conduct a more important catalytic degradation of $\mathrm{H}_{2} \mathrm{O}_{2}$. Nevertheless, overabundant quantities of $\mathrm{Fe}^{2+}$ may as well conduct to scavenging of ${ }^{\circ} \mathrm{OH}$, which will curb the technique efficiency [57]. Moreover, an elevated level of $\mathrm{Fe}^{2+}$ may as well conduct to an elevated sludge formation at the end of the method. As a re- 
sult, the ratio of $\mathrm{H}_{2} \mathrm{O}_{2}$ to $\mathrm{Fe}^{2+}$ is a critical precaution to guarantee the optimum formation of ${ }^{\circ} \mathrm{OH}$ and avert the scavenging impact.

The wastewater $\mathrm{pH}$ is an additional crucial factor touching Fenton process. Generating ${ }^{\circ} \mathrm{OH}$ is governed by the $\mathrm{pH}$ of the reaction medium; indeed, more elevated $\mathrm{pH}$ conducts to the precipitation of $\mathrm{Fe}$ (III) in the form of iron hydroxideflocs [1] [58]. Therefore, the formation of ${ }^{\circ} \mathrm{OH}$ and the dependent decomposition of contaminants via the Fenton process is efficient below acidic $\mathrm{pH}$, i.e., in the interval of 2.8 - 3.5 [59] [60] [61]. In other words, the $\mathrm{pH}$ of the wastewater should be regulated inside this domain to guarantee ferrous and ferric irons with a view to preserve their catalytic capacity [62]. As mentioned above, the temperature was counted to possess an unfavorable influence on Fenton response. This was attributed to the worry for probable degradation of $\mathrm{H}_{2} \mathrm{O}_{2}$ above $90^{\circ} \mathrm{C}$ and the energy necessity [63]. Therefore, researches on Fenton methods have widely been performed below ambient temperature. Nevertheless, modern investigations have proved that augmented temperatures may elevate the oxidation rate and improve Fenton's response. For instance, scientists [64] noted an amelioration of the transformation of linear alkylbenzenesulfonate through Fenton reaction if the temperature was elevated from $20^{\circ} \mathrm{C}$ to $94^{\circ} \mathrm{C}$. At the lower temperature, $61 \%$ transformation was reached, which augmented to $99.9 \%$ at the higher temperature. Many fresh investigations have as well shown the improvement of Fenton response at more increase temperature [65] [66]. The favorable impact of higher temperatures may be addressed to a more performant utilization of $\mathrm{H}_{2} \mathrm{O}_{2}$, which conducts to the more important formation of ${ }^{\circ} \mathrm{OH}$ [67]. The type of reaction matrix stays a crucial factor as the existence of organic/inorganic chemicals in wastewater may lead to a scavenging impact on the ${ }^{\circ} \mathrm{OH}$. Mineral chemicals like $\mathrm{NaCl}, \mathrm{Na}_{2} \mathrm{CO}_{3}$, and $\mathrm{Na}_{2} \mathrm{SO}_{3}$ are detected in different levels in genuine wastewaters and may react with ${ }^{\circ} \mathrm{OH}$, diminishing their accessibility [68].

The Fenton process undergoes many restrictions that prevent its large-scale usages. One of such barrier remains the immoderate formation of iron sludge that causes troubles in the recycling and can lead to resultant contamination. Additional restrictions involve the need for a limited domain of working $\mathrm{pH}$ and elevated chemical inputs [69]. As a consequence, handling the disadvantages of the Fenton process constitutes an endless study attempt in the area of the Fenton method for recalcitrant wastewater treatment. Many of the procedures to deal with such restrictions comprise the employment of heterogeneous Fenton process [70] [71], fluidized-bed Fenton technique [72], and electro-Fenton [73].

\section{Fenton Technology for Recalcitrant Wastewater Treatment: Review Papers' State of the Art}

The domain of Fenton technology for recalcitrant wastewater treatment was the subject of numerous review papers. Such literature discussions focused on diverse features of the Fenton technique comprising the basis and usages of conventional Fenton oxidation, heterogeneous Fenton process, electro-Fenton with its related processes, fluidized-bed Fenton process, Fenton process at circum- 
neutral $\mathrm{pH}$ employing chelating agents and hybrid techniques, where Fenton reaction is integrated with additional techniques. Several review papers embraced the large domain of AOPs, like those mentioned by Oturan and Aaron [74], in which the Fenton process is evaluated with different AOPs. Nevertheless, Bello et al. [1] in their work largely encompassed those reviews where Fenton oxidation is the main interest (see in [1] (their Table 1) for a summary of many of these reviews).

Neyens and Baeyens [30] presented an evaluative survey of the conventional Fenton process, concentrating on the kinetics, the impact of running factors, the importance of the ratio of Fenton's reagent and the usage of Fenton method in sludge dewatering. In the following publication, Pignatello et al. [75] offered a global discussion of the pathways of Fenton and Fenton-similar processes, reaction routes and intermediates, changed configurations of Fenton process (heterogeneous Fenton, photo-helped Fenton [76], etc.) and their usages to water and soil remediation. More lately, scientists [77] [78] displayed analysis of Fenton-similar technologies for organic wastewater remediation. They concentrated on running factors, changed Fenton-similar methods, catalysts, and economic considerations [1].

Brillas et al. [79] published a thorough discussion of the electro-Fenton and similar electrochemical techniques that are founded on Fenton's response. They focused on the basics of Fenton's chemistry, the progression of the electro-Fenton method, cell arrangement, working factors, pathways, integrated electroFenton techniques, and their ecological utilizations. Newly, Poza-Nogueiras et al. [80] suggested an analysis of the present tendencies and developments in electro-Fenton technology focusing on the implementation of heterogeneous catalysts. They concentrated on the diverse sorts of catalysts and elaboration procedures, the influence of running indicators, pathways and usages in treating water, soil and adsorbent renewal. Researchers [81] evaluated the basic concepts and usages of electro-Fenton technology. The review concentrated on the kinds of catalyst and functionalized cathodic materials, route of catalytic activation of $\mathrm{H}_{2} \mathrm{O}_{2}$ and setup arrangement. A discussion of the bio-electro-Fenton was lately published by Li et al. [82] [83] who focused on its basics, working factors, reactor conception, and economic features [1].

Table 1. Probable impacts of $\mathrm{pH}$ on Fenton process [1].

\begin{tabular}{|c|c|c|c|}
\hline pH below optimum & Reference & pH above optimum & Reference \\
\hline Scavenging of ${ }^{\bullet} \mathrm{OH}$ by excess $\mathrm{H}^{+}$ & {$[88]$} & $\begin{array}{l}\text { Deficiency of } \mathrm{H}^{+} \text {, which } \\
\text { hampers }{ }^{\circ} \mathrm{OH} \text { formation }\end{array}$ & [59] \\
\hline $\begin{array}{c}\text { Formation of }\left[\mathrm{Fe}\left(\mathrm{H}_{2} \mathrm{O}\right)\right]^{2+} \\
\text { which has low oxidative power }\end{array}$ & [89] & Decomposition of $\mathrm{H}_{2} \mathrm{O}_{2}$ & {$[90]$} \\
\hline $\begin{array}{l}\text { Prevent the interaction } \\
\text { between } \mathrm{Fe}^{3+} \text { and } \mathrm{H}_{2} \mathrm{O}_{2}\end{array}$ & {$[91]$} & $\begin{array}{l}\text { Decline in the oxidative } \\
\text { power of }{ }^{\circ} \mathrm{OH}\end{array}$ & {$[92]$} \\
\hline $\begin{array}{c}\mathrm{H}_{2} \mathrm{O}_{2} \text { may be unstable to formed } \\
\mathrm{H}_{3} \mathrm{O}_{2}^{+} \text {which impedes } \\
\text { production of }{ }^{\cdot} \mathrm{OH}\end{array}$ & {$[93]$} & $\begin{array}{l}\text { Precipitation of } \mathrm{Fe}^{3+} \\
\text { as iron hydroxide }\end{array}$ & {$[60][61]$} \\
\hline
\end{tabular}


Even if such analyses have embraced the basics of Fenton reaction and identical methods, a discussion concentrating on the main restrictions of Fenton technology and the new development to treating them has not been given until the excellent work done by Bello et al. [1]. Indeed, they discussed the fresh advance to dealing with the main restrictions of Fenton's response for recalcitrant wastewater treatment. Primarily, they analyzed the restrictions of Fenton technology, pursued by a pertinent discussion of the modern references on probable procedures for dealing with such restrictions. For each action plan, they assessed the basics and exemplary implementations in decomposing recalcitrant organic contaminants. They also suggested viewpoints on potential orientations for the next research. In fact, Bello et al. [1]'s analysis remains appropriate because of the augmenting investigation works to resolving the restrictions of the Fenton technology.

\section{Restrictions of Fenton Process and Procedure to Deal with Them}

\subsection{Fluidized-Bed Fenton Process}

The Fenton process has many obstacles that prevent its industrial implementation. Fenton technique is greatly touched by the solution $\mathrm{pH}$, which requires to be fixed in the acidic domain to avert the precipitation of $\mathrm{Fe}^{3+}$ into iron hydroxide $\left(\mathrm{Fe}(\mathrm{OH})_{3}(\mathrm{~s})\right)$. Table 1 recaps the impacts of $\mathrm{pH}$ outside the optimum domain. The necessity of delicate dominance of $\mathrm{pH}$ and the hardness of running in acidic circumstances stop the workable implementations of Fenton technology [84]. Bigger $\mathrm{pH}$ conducts to complexation reactions and precipitation of iron oxides, causing the formation of excessive sludge. As a result, sludge production constitutes one more inconvenient of the traditional Fenton process [85] [86]. Sludge formation opens the hazard of additional contamination and the necessity for sludge remediation and recycling. The necessity of supplementary remediation of sludge is an origin of worry since the cost of sludge remediation may be above to $35 \%-50 \%$ of the total operating cost of the wastewater treatment [30]. More difficulties of the Fenton process involve elevated chemical utilization, instability of the Fenton's reagent, undesirable reactions and loss of oxidant, hardness in regulating the reagent concentrations and the exigency to neutralize the treated wastewater prior recycling [75] [87]. Table 2 underlines the main restrictions of the Fenton technique and several of the likely procedures to deal with them [1].

There is increasing attention in investigations to resolve the restrictions of the traditional Fenton process. Not many steps have appeared as likely solutions as listed in Table 2. One such procedure remains the expansion of heterogeneous Fenton oxidation, in which iron oxides or other metal oxides are employed as heterogeneous catalysts [38]. Fluidized-bed Fenton technique is second planning, in which a fluidized-bed reactor is integrated with the homogeneous Fenton reaction to enhance process efficiency and decrease sludge formation. An additional manner implicates performing Fenton oxidation at near-neutral $\mathrm{pH}$ 
Table 2. Mainrestrictions of classical Fenton process and their likely solutions [1].

\begin{tabular}{|c|c|c|c|c|}
\hline S/N & Restriction & Causes & Probable solutions & References \\
\hline 1 & $\begin{array}{l}\text { Requirement of acidic } \\
\mathrm{pH} \text { (narrow range of } \\
\text { operational } \mathrm{pH} \text { ) }\end{array}$ & $\begin{array}{l}\text { - Production of }{ }^{\circ} \mathrm{OH} \text { requires acidic } \mathrm{pH} \\
(2.5-3.5) \\
\text { - Acidic } \mathrm{pH} \text { is required to keep } \\
\mathrm{Fe}^{2+} \text { in soluble form } \\
\text { - } \mathrm{pH} \text { above } 4 \text { promotes complex } \\
\text { formation and sludge generation }\end{array}$ & $\begin{array}{l}\text { Use of heterogeneous catalyst (iron oxide, } \\
\text { transition metal, composites, etc.) } \\
\text { Use of chelating agents such as EDTA, } \\
\text { oxalate, etc. }\end{array}$ & {$[62][84][94]$} \\
\hline 2 & $\begin{array}{l}\text { Excessive sludge } \\
\text { generation }\end{array}$ & - Neutralization of the Fenton reaction & $\begin{array}{l}\text { - Fluidized-bed Fenton process } \\
\text { - Heterogeneous Fenton } \\
\text { - Electro-Fenton }\end{array}$ & [69] [72] [95] [96] \\
\hline 3 & $\begin{array}{l}\text { Chemical } \\
\text { consumption/cost of } \\
\text { chemicals }\left(\mathrm{H}_{2} \mathrm{O}_{2}\right)\end{array}$ & $\begin{array}{l}\text { - Large amount of } \mathrm{H}_{2} \mathrm{O}_{2} \text { may be } \\
\text { necessary to completely mineralize } \\
\text { pollutants } \\
\text { - } \\
\text { Scavenging of } \mathrm{H}_{2} \mathrm{O}_{2} \\
\text { anions/cationspresent }\end{array}$ & $\begin{array}{l}\text { - Use of electro-Fenton/bio-electro-Fenton } \\
\text { and other technologies with in situ } \\
\text { generation of } \mathrm{H}_{2} \mathrm{O}_{2} \\
\text { - Other alternative } \text { oxidants }^{\text {. }}\end{array}$ & [77] [78] [97] \\
\hline
\end{tabular}

via the introduction of a chelating chemical to produce iron-complexes [60] [61]. Manners able of in situ generation of oxidants $\left(\mathrm{H}_{2} \mathrm{O}_{2}\right)$ like electro-Fenton and bio-electro-Fenton (microbial fuel cell) stay interesting techniques for treating the elevated chemical necessity. Bello et al. [1] analyzed such procedures below four classes: 1) fluidized-bed Fenton process, 2) heterogeneous Fenton processes, 3) Homogeneous Fenton at neutral $\mathrm{pH}$ using chelating agents and, 4) in situ production of Fenton's reagent.

Immoderate sludge formation is between the main imperfections of the conventional Fenton reaction [1]. Several scientists have tried the application of a fluidized-bed reactor to realize Fenton's response, the so-named fluidized-bed Fenton process. In the fluidized-bed Fenton process, solids carriers, such as $\mathrm{SiO}_{2}$ (Figure 1), are employed to trigger the crystallization of iron oxide and diminish sludge production [95] [98]. The fluidization improves mixing and raises ${ }^{\circ} \mathrm{OH}-$ contaminant interaction. Further, recirculation gives more oxygen into the setup, which may improve the technique efficiency by keeping ${ }^{\circ} \mathrm{OH}$ [99].

The first investigation on the fluidized-bed Fenton process was published by Chou and Huang [100]. They examined the oxidation of benzoic acid. Huang and Huang [101] [102] applied Fenton oxidation for decomposing phenol in a fluidized-bed setup. In the same way, Anotai et al. [103] noted the decomposition of nitrobenzene and iron crystallization employing a fluidized-bed Fenton process [1]. Following researches were mainly oriented to sludge decrease and process efficiency in decomposing diverse recalcitrant contaminants like dimethyl sulfoxide [98], dyes [104], bisphenol A [105] and phthalocyanine (Figure 2) [106].

\subsection{Electro-Fenton Process}

Using electrochemical technology in the Fenton oxidation is rising as an encouraging option. In electrochemical technology, the electron is employed as the 


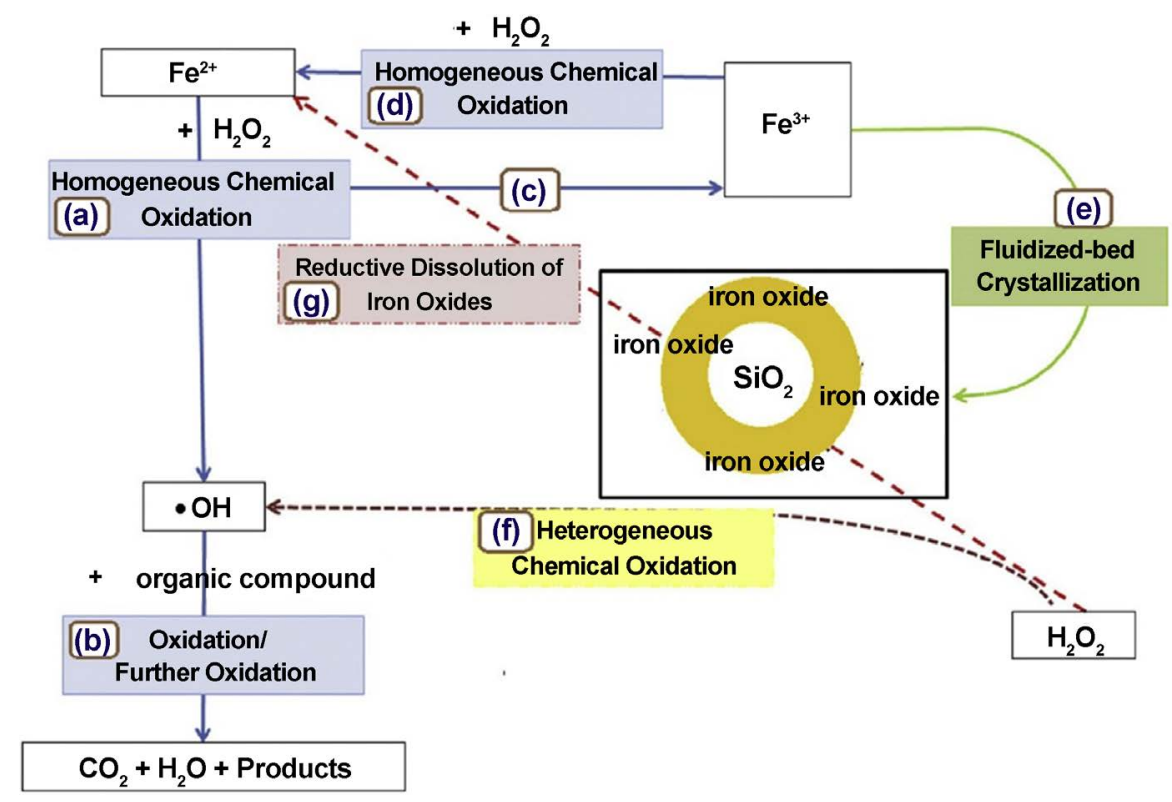

Figure 1. Various processes that occur in fluidized-bed Fenton process using $\mathrm{SiO}_{2}$ as carriers, 1) homogeneous reaction between $\mathrm{Fe}^{2+}$ and $\mathrm{H}_{2} \mathrm{O}_{2}, 2$ ) crystallization of $\mathrm{Fe}^{3+}$ on the surface of $\mathrm{SiO}_{2}, 3$ ) heterogeneous reaction between crystallized iron oxide and $\mathrm{H}_{2} \mathrm{O}_{2}$ and, 4) reductive dissolution of iron oxide [1].

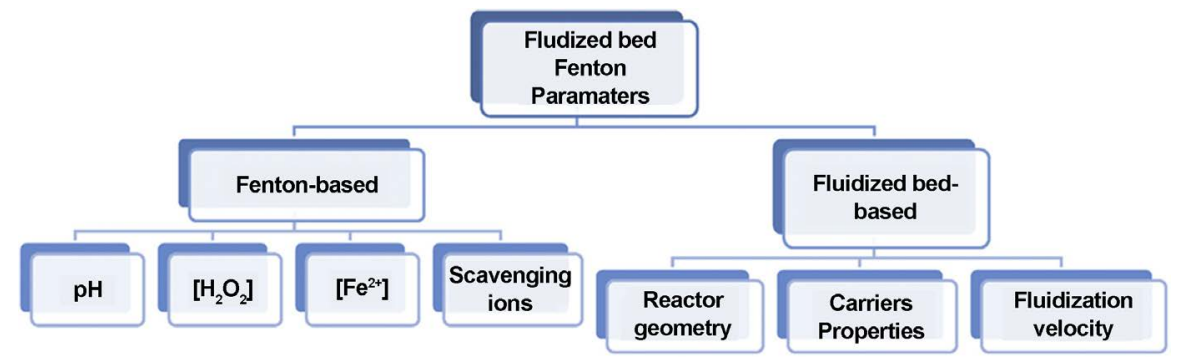

Figure 2. Mainrunning factors of fluidized-bed Fenton process [1].

reagent to push the treatment method. Various choices may be acquired if electrochemical technology is implemented to Fenton oxidation. Between such, two manners could give an in situ production of Fenton's reagent. During the first manner, the electro-Fenton process, $\mathrm{H}_{2} \mathrm{O}_{2}$ is constantly formed at the cathode while the iron catalyst is externally introduced. The second procedure, the anodic Fenton process, implicates the utilization of sacrificial iron anode for the electrogeneration of $\mathrm{Fe}^{2+}$ while $\mathrm{H}_{2} \mathrm{O}_{2}$ is formed at the cathode or externally injected [1]. As numerous researches have usually grouped the latter as an electro-Fenton technology, it is really a peroxi-coagulation method, in which the contaminant is eliminated by the integrated oxidation and coagulation caused by the existence of $\mathrm{Fe}(\mathrm{OH})_{3}$ [79]. A thorough analysis of the electro-Fenton process and similar electrochemical techniques was published by Brillas et al. [79]; however, more fresh discussions of the basic concepts and environmental utilization of the electro-Fenton process were suggested by Poza-Nogueiras et al. [80] and Ganiyu et al. [81]. 
Usually, electro-Fenton is planned to possess a constant electrogeneration of $\mathrm{H}_{2} \mathrm{O}_{2}$ at the cathode. In a regular process, air/ $\mathrm{O}_{2}$ is constantly furnished to the cathode; at the same time, the production of $\mathrm{H}_{2} \mathrm{O}_{2}$ is caused by a two-electron reduction of $\mathrm{O}_{2}$ in acidic medium as illustrated in Equation(7) [63]. The introduction of $\mathrm{Fe}^{2+}$ leads to the catalytic degradation of $\mathrm{H}_{2} \mathrm{O}_{2}$ to form ${ }^{\circ} \mathrm{OH}$ founded on Fenton's reaction. Moreover, there is a constant electroregeneration of $\mathrm{Fe}^{2+}$ at the cathode as defined by Equation (8) [1].

$$
\begin{gathered}
\mathrm{O}_{2}+2 \mathrm{H}^{+}+2 \mathrm{e}^{-} \rightarrow \mathrm{H}_{2} \mathrm{O}_{2} \\
\mathrm{Fe}^{3+}+\mathrm{e}^{-} \rightarrow \mathrm{Fe}^{2+}
\end{gathered}
$$

As Fenton's reagent is produced in situ employing electron, which is a clean species, many of the restrictions of the classical Fenton oxidation may be avoided. With the constant in situelectrogeneration of $\mathrm{H}_{2} \mathrm{O}_{2}$, the prices related to direct external injection of $\mathrm{H}_{2} \mathrm{O}_{2}$ will be avoided. Contrasted to the price of the external addition of $\mathrm{H}_{2} \mathrm{O}_{2}$, Huang and $\mathrm{Chu}$ [107] affirmed that up to $80 \%$ cost decrease may be attained with the in situelectrogeneration of $\mathrm{H}_{2} \mathrm{O}_{2}$. This price diminution will even augment when the costs related to transportation and storage of $\mathrm{H}_{2} \mathrm{O}_{2}$ are factored in [1]. This constitutes one of the benefits of electro-Fenton process contrasted to the conventional Fenton oxidation. An additional benefit of electro-Fenton process is the constant formation of $\mathrm{Fe}^{2+}$ (Equation (8)), which could reduce the potential sludge production from the precipitation of $\mathrm{Fe}^{3+}$. Further, the constant regeneration of $\mathrm{Fe}^{2+}$ will diminish the catalyst input and improve the formation of ${ }^{\circ} \mathrm{OH}$ [63].

The performance of electro-Fenton is a function of numerous factors like applied current, solution $\mathrm{pH}$, sort of electrolyte, the quantity of catalyst and the initial level of target contaminant. The impacts of solution $\mathrm{pH}$, catalyst level and initial level of contaminant on electro-Fenton are identical to the classical Fenton oxidation. As an illustration, the optimum $\mathrm{pH}$ for efficient electro-Fenton was mentioned to be in the interval of 2.5 - 3.5 [74]. Applied current is a basic factor that touches the efficiency of electro-Fenton. The electrogeneration of $\mathrm{H}_{2} \mathrm{O}_{2}$ and the constant regeneration of $\mathrm{Fe}^{2+}$ are a function of the applied current. As a result, the performance of electro-Fenton augments with the augmentation in the applied current. Nevertheless, elevating the applied current over specific end may add parasitic reactions into the technique, decreasing the contaminant decomposition performance. The optimum quantity of applied current is application-specific and could be evaluated by early trials [1].

Several investigations have proved the performance of electro-Fenton to produce in situ Fenton's reagent for following decomposition of organic contaminants. Aside from the benefit of price diminution, efficacious decompositions of pollutants have been noted. On the other hand, the energy demand stays a worry in the electro-Fenton process [1].

\subsection{Bio-Electro-Fenton (Microbial Fuel Cell)}

The employment of microbial fuel cells (MFCs) to produce $\mathrm{H}_{2} \mathrm{O}_{2}$ for Fenton 
oxidation, the so-named bio-electro-Fenton, is rising as an encouraging technique to diminish the cost linked to $\mathrm{H}_{2} \mathrm{O}_{2}$ purchase and transportation [77] [78]. In MFCs including an anode and cathode compartments, microorganisms are utilized to transform the chemical energy stored in organic pollutants to produce electric current and chemicals [108] [109]. The electrons are formed at the anaerobic anode compartment comprising the organic substrate and transported to the cathode compartment via an external circuit [110]. At the cathode, the two-electron oxygen reduction conducts to the generation of $\mathrm{H}_{2} \mathrm{O}_{2}$. With the formation of $\mathrm{H}_{2} \mathrm{O}_{2}$, Fenton catalyst $\left(\mathrm{Fe}^{2+}\right.$, iron oxide) can be introduced into the setup for the catalytic degradation of the $\mathrm{H}_{2} \mathrm{O}_{2}$ to form ${ }^{\circ} \mathrm{OH}$ [1]. Figure 3 illustrates a schematic of a typical MFC employed in Fenton process (bio-electroFenton process). The simultaneous formation of $\mathrm{H}_{2} \mathrm{O}_{2}$ and electricity production make bio-electro-Fenton an interesting technique for wastewater treatment. Information about the basics of bio-electro-Fenton method may be read in the reviews published by Li et al. [82] [83].

The first published investigation on the bio-electro-Fenton was the research of Zhu and Ni [111]. They studied the decomposition of p-nitrophenol with simultaneous electricity production. Since then, numerous researches have noted the efficient employment of MFC to produce $\mathrm{H}_{2} \mathrm{O}_{2}$ for Fenton oxidation with concomitant electricity production. Mai and $\mathrm{Li}$ [110] concentrated on the usage of bio-electro-Fenton for decomposing Orange II at neutral $\mathrm{pH}$. The maximum $\mathrm{H}_{2} \mathrm{O}_{2}$ formed was $3.24 \mathrm{mg} / \mathrm{L}$, leading to total decomposition of the dye following $14 \mathrm{~h}$ and simultaneous power production of $230 \mathrm{~mW} / \mathrm{m}^{2}$. In identical research, Feng et al. [112] attained an $\mathrm{H}_{2} \mathrm{O}_{2}$ formation of $2.86 \mathrm{mg} / \mathrm{L}$, conducting to total mineralization of Orange II. As an alternative of the dual-chamber usually utilized in the bio-electro-Fenton, Zhu and Logan [113] proposed a single-chamber MFC setup for decomposing phenol. The technology reduced more than $75 \%$ of total organic carbon (TOC) from the phenol-containing solution. Even if the

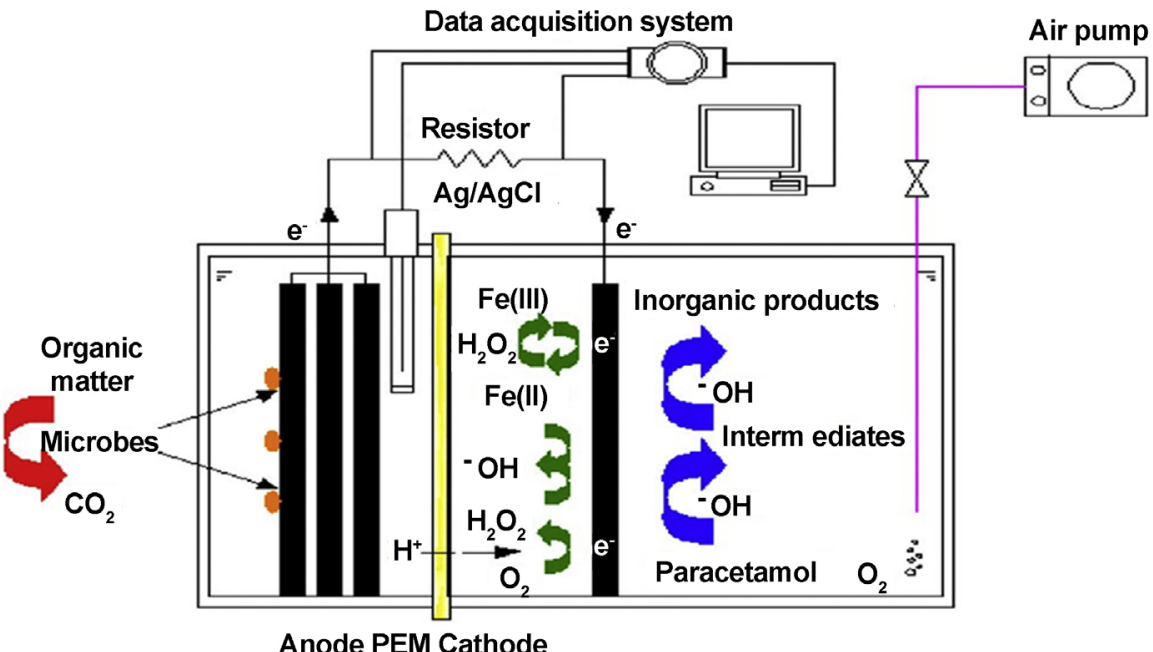

Figure 3. Schematic of microbial fuel cell applied to Fenton oxidation (PEM = Proton Exchange Membrane) [1]. 
single-chamber device is depicted to possess higher performance and lower operational cost, the quantity of $\mathrm{H}_{2} \mathrm{O}_{2}$ formed was not evaluated [1].

More fresh investigations of bio-electro-Fenton comprise the research of Li et al. [114]. Their main focus was the technique of employing a microbial reverse-electrodialysis electrolysis cell for decomposing Orange G. The fundamental characteristic of the device is that the electrons are formed from the exoelectrogens and salinity-gradient among seawater and freshwater in the cell. The technology conducted to the TOC elimination performance of $99.6 \%$. Zhang et al. [115] tried the bio-electro-Fenton oxidation of paracetamol employing a dual-chamber MFC. The method eliminated until $70 \%$ of the initial paracetamol under optimum condition [1].

One main worry with the bio-electro-Fenton process remains the formation of $\mathrm{O}_{2}$ as an alternative to the wanted $\mathrm{H}_{2} \mathrm{O}_{2}$. To make sure the selectivity of cathode material for $\mathrm{H}_{2} \mathrm{O}_{2}$ generation, few scientists have proposed the employment of carbonaceous cathode as an alternative to the highly expensive Pt cathode. Carbon-founded materials are encouraging thanks to low price, plenty and electro-reduction activity. Wang et al. [77] [78] tried the reduction of bisphenol A, estrone, sulfamethazine and triclocarban employing bio-electro-Fenton with a graphite electrode. The maximum concentration of $\mathrm{H}_{2} \mathrm{O}_{2}$ formed was $2.06 \mathrm{mg} / \mathrm{L}$. On the other hand, Asghar et al. [116] reached a maximum $\mathrm{H}_{2} \mathrm{O}_{2}$ production of $140 \mathrm{mg} / \mathrm{L}$ with a simultaneous electricity formation of $33.52 \mathrm{~W} / \mathrm{m}_{2}$ employing a heat-treated graphite cathode. Because of poor catalytic activity of carbonaceous material, higher yields of $\mathrm{H}_{2} \mathrm{O}_{2}$ has not been attained [1].

To obtain enhancement in the production of $\mathrm{H}_{2} \mathrm{O}_{2}$, heteroatom doping of carbonaceous cathode is one of the proposed solutions [117]. In this attention, nitrogen doping has proved to be an efficacious procedure as it changes the electronic features of the carbon material and elevates the electrochemical surface area. Numerous researchers have established the contribution of nitrogen doping on $\mathrm{H}_{2} \mathrm{O}_{2}$ formation and power yields. For example, Asghar et al. [118] have proved a $25 \%$ augmentation in the yield of $\mathrm{H}_{2} \mathrm{O}_{2}$ formation through treating graphite cathode with $\mathrm{NH}_{3}$ at elevated temperature. In addition, in many publications, $\mathrm{H}_{2} \mathrm{O}_{2}$ formation rates of $1.7-121 \mathrm{mmol} / \mathrm{h} / \mathrm{g}$ are reached employing $\mathrm{N}$-doped porous carbon [119]. Lately, Wang et al. [120] altered activated carbon air cathode by co-pyrolyzing with glucose and doping with nano-zero-valent iron to enhance two-electron oxygen reduction in the bio-electro-Fenton process. The changed electrode showed higher decomposition performance and more power production contrasted to pure activated carbon. Further, the anti-biofouling impact was noted on the altered cathode following an extended period of running [1].

Even if researches have proved the feasibility of the in-situ formation of $\mathrm{H}_{2} \mathrm{O}_{2}$ in the bio-electro-Fenton setup, there are numerous dares like the low generation of $\mathrm{H}_{2} \mathrm{O}_{2}$, membrane fouling [121] [122], high internal resistance and reactor arrangements that require more revision prior its commercial implementations [1]. 


\section{Electro-Fenton Process for Disinfecting Water}

Ren et al. [123] tested a breakthrough by one method of new flow-through electro-Fenton with a graphene-modified cathode, which is frequently considered to be inefficient. They established that this technique was cost-effective for concomitant sulfadiazines (SDZs) decomposition and disinfection [124] [125] from urban secondary effluent with an extremely low electrical energy consumption (EEC) of $0.21 \mathrm{kWh} / \mathrm{m}^{3}$, explained to the elevated $\mathrm{H}_{2} \mathrm{O}_{2}$ formation of $4.41 \mathrm{mg} / \mathrm{h} / \mathrm{cm}^{2}$ on the fresh graphite felt cathode altered by electrochemically exfoliated grapheme (EEGr) with a low EEC of $3.08 \mathrm{kWh} /\left(\mathrm{kg} \mathrm{H}_{2} \mathrm{O}_{2}\right)$. Contrasted with the inefficient SDZs decomposition by the traditional flow electro-Fenton, this technology was more cost-efficient and overpass the harsh needs of the electrolyte level. Further, it depicted excellent performance in decomposing diverse antibiotics, and the graphene-modified cathode still kept stable performance following eight subsequent trials. Taking into consideration the integrated work of ${ }^{\bullet} \mathrm{OH}$ and active chlorine [126] [127] [128] [129] [130], the generation of hydroxylated and chlorine-containing by-products [131] was proved, and a likely decomposition route for SDZs was suggested. This flow-through electro-Fenton technique presented a substitutional process for killing pathogens and decomposing antibiotics through single technology for treating and reusing domestic secondary effluent (Figure 4).

\section{Bio-Electro-Fenton Processes for Disinfecting Water}

As mentioned previously, the bio-electrochemical technology-assisted advanced oxidation reactions (that is the bio-electro-Fenton system) have found an ideal position where they may be controlling in the next years, particularly for reducing recalcitrant organic contaminants. Contrasted to the classical electro-Fenton techniques, the bio-electro-Fenton setup hugely diminished the expenditures on wastewater treatment in terms of electric energy consumption and running prices. The bio-electro-Fenton setup is beginning to be a flexible technique providing a novel solution for emerging environmental problems linked with wastewater treatment. Li et al. [83] deeply examined the present publications concerning the decomposition of the recalcitrant organic contaminants in the bioelectro-Fenton device, particularly focusing on the treatment efficiency related to reactor design and major working factors.

As bio-electro-Fenton has been widely examined for eliminating recalcitrant organics, its implementation capacity vis-a-vis disinfecting water (that is killing pathogens) staysnot familiar. Zhou et al. [132] tried the demobilization of Escherichia coli [133]-[139] in a microbial electrolysis cell-based bio-electroFenton setup (recalled as a microbial electrolytic-Fenton cell) with the objective to widen the utilization of microbial electrochemistry. They observed that a 4-log lowering of E. coli ( 107 to hundreds $\mathrm{CFU} / \mathrm{mL}$ ) was attained with an external applied voltage of $0.2 \mathrm{~V}, 0.3 \mathrm{mM} \mathrm{Fe} \mathrm{F}^{2+}$ and cathodic $\mathrm{pH}$ of 3.0 (Figure 5). Nevertheless, unimportant demobilization was detected in the control tests 

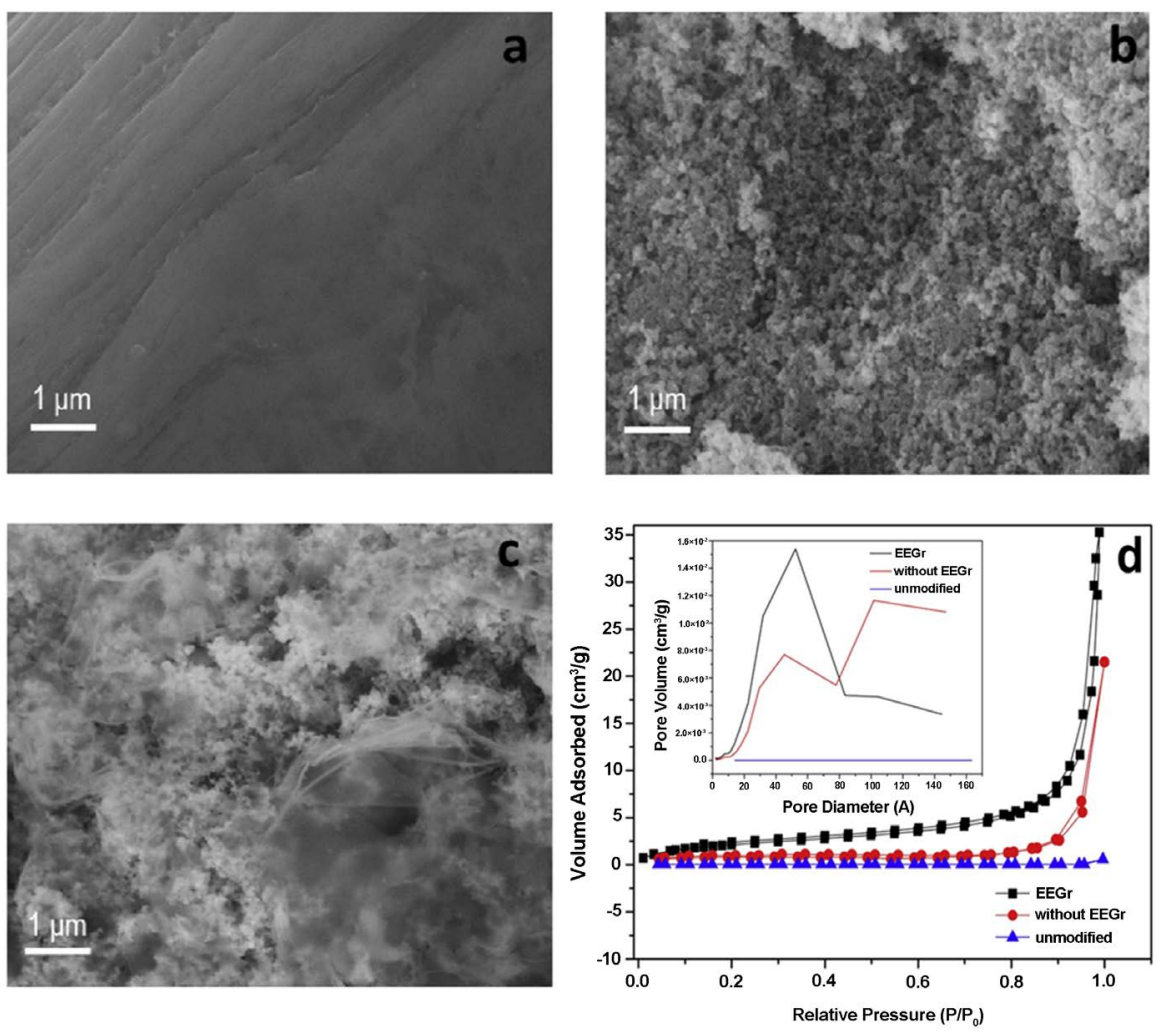

Figure 4. The Scanning electron microscopy (SEM) of unmodified (a), without electrochemically exfoliated grapheme (EEGr); (b) and EEGr; (c) modified graphite felts; $\mathrm{N}_{2}$ adsorption/desorption isotherms and the pore size distribution of three different graphite felts (unmodified, without EEGr and EEGr) (d) [123].

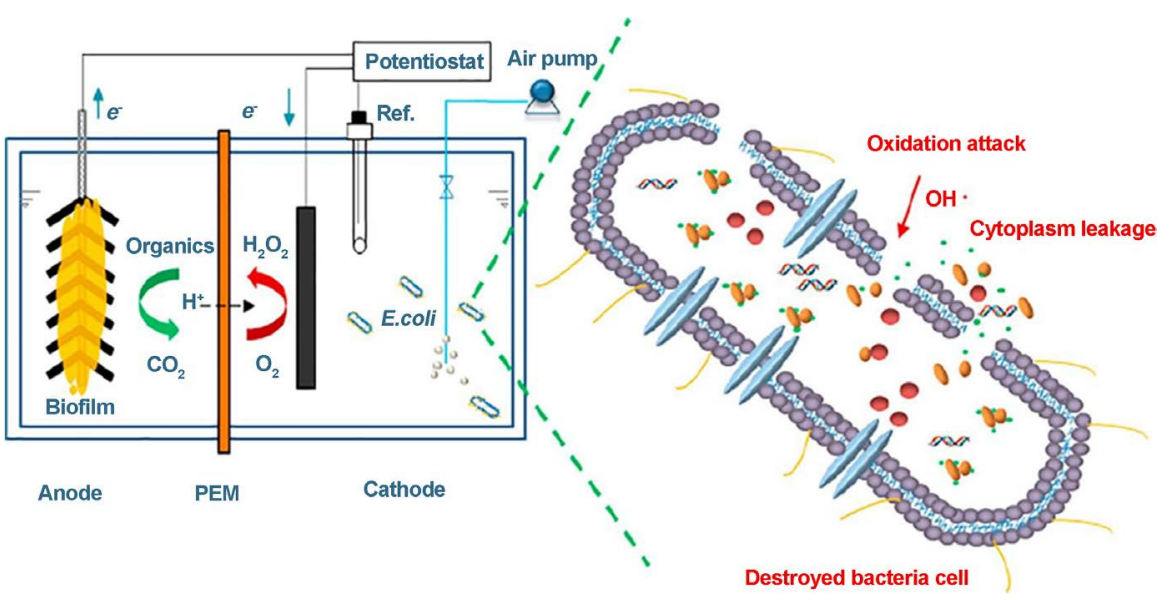

Figure 5. Schematic illustration of disinfection in Bio-electro-Fenton System [132].

without external voltage or $\mathrm{Fe}^{2+}$ injection. The killing microorganisms' impact was improved when the cathode airflow rate augmented from 7 to $41 \mathrm{~mL} / \mathrm{min}$ and was also proportional to the elevation of $\mathrm{Fe}^{2+}$ level from 0.15 to $0.45 \mathrm{mmol} / \mathrm{mL}$. Lethal cell film demolition via ${ }^{\circ} \mathrm{OH}$ was described as one probable route for disinfection (Figure 6). Zhou et al. [132] successfully established the likelihood of the bio-electro-Fenton technique for killing pathogens inactivation that provides 


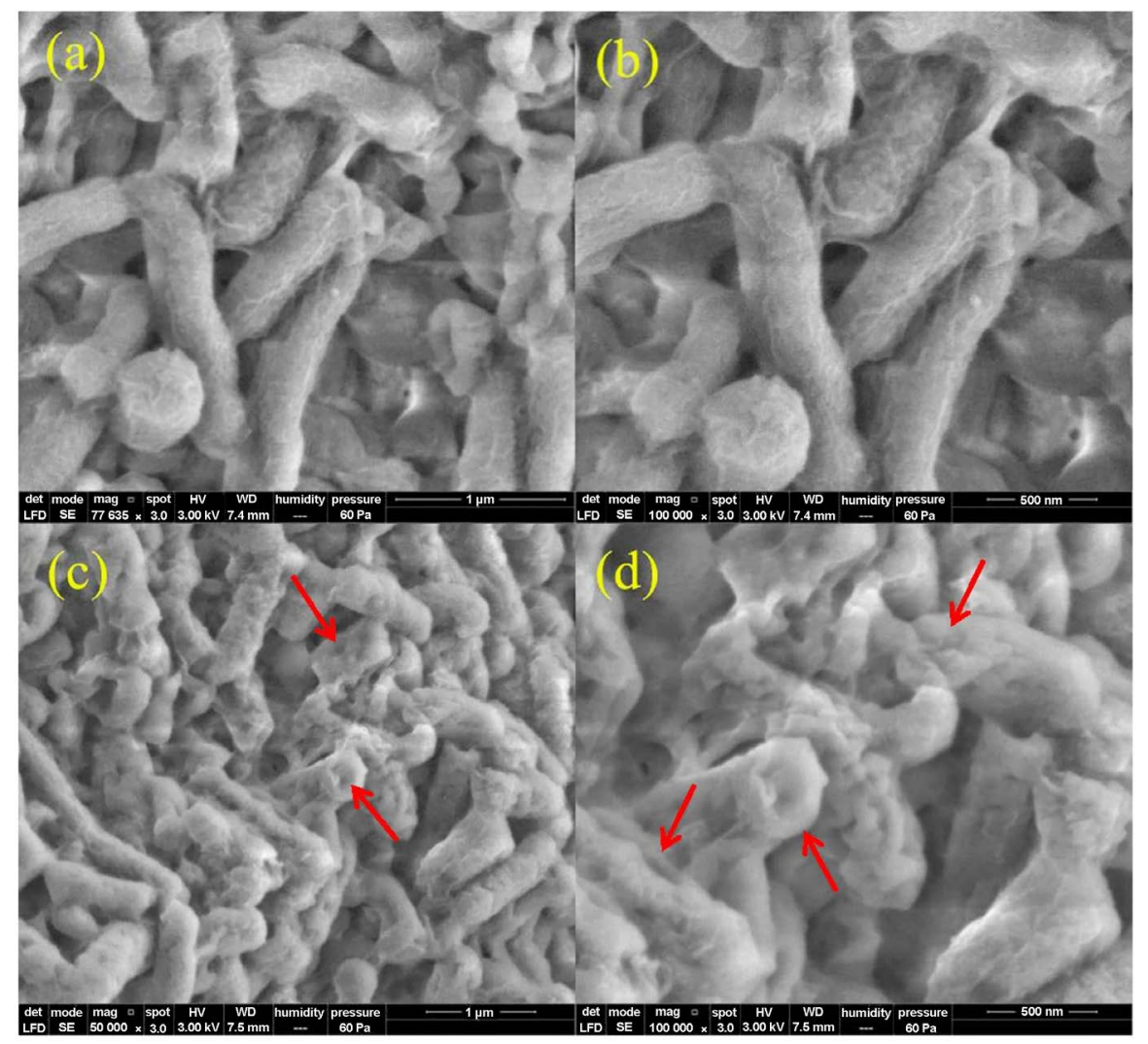

Figure 6. SEM images of $E$. coli (a) (b) untreated, (c) (d) after bio-electro-Fenton treatment for $60 \mathrm{~min}$ (arrows indicated that the collapses in cellular structure) [132].

comprehension for the coming expansion of possible, performant, and cost-effective biological [140] [141] water treatment technology.

\section{Fenton Technologies: Hybridization as Main Future Trend}

Despite the progress registered in the Fenton technologies, the classical process, and its ameliorated versions, adsorption and/or membranes processes [142] [143] [144] [145] remain fundamental for secure wastewater treatment.

In this context, Rogers et al. [146] established the chance of a toilet setup that recycles blackwater for onsite reuse as flush water, in which the blackwater is electrochemically treated to eliminate pathogens due to fecal pollution. Nevertheless, they found that this electrochemical technique needs great energy (48 $93 \mathrm{~kJ} / \mathrm{L}$ ) to obtain total disinfection of the process liquid, and the disinfected liquid retains color and chemical oxygen demand (COD). Granular activated carbon (GAC) efficaciously diminishes COD in concentrated wastewaters. Rogers et al. [146] supposed that decreasing COD with GAC before the electrochemical application would enhance disinfection energy. They expanded and tried a hybrid system that integrates these techniques and proved its capacity to attain complete disinfection with elevated energy efficiency and liquid quality more appropriate for onsite reuse and/or discharge. Their hybrid setup combining both the pre- and post-treatment GAC filters with electrochemical treatment conducted 
to a considerable decrease in the steady-state levels of numerouspollutants contrasted to the identical device without GAC (Figure 7). Mostimportantly, 1) the COD of the process liquid was diminished by $69 \%$, and 2) the appearance of the water was hugely enhanced proved by the decreases in turbidity and color. The energy needed for total disinfection was diminished by $71 \%$ to $20 \mathrm{~kJ} / \mathrm{L}$ with the addition of both pre- and post-treatment GAC filters. This energy decrease is probably attributed to the diminution in specifically soluble COD [146].

Lei et al. [147] suggested an electrochemical dynamic membrane filtration (EDMF) device for concomitant solid-liquid separation (also preserving electrodes against fouling) and sewage disinfection (Figure 8). At a low voltage of $2.5 \mathrm{~V}$, efficacious disinfection was obtained in the EDMF, with $\sim 100 \% \log$ elimination performance (no detectable bacteria in the effluent). They proved that the EDMF setup, run at membrane flux of $100 \mathrm{~L} /\left(\mathrm{m}^{2} \cdot \mathrm{h}\right)$, may keep long-lasting bacterial disinfection performance of real wastewater $(\sim 100 \%$ log removal) in continuous flow trials (Figure 9). Transmembrane pressure (TMP) augmented from $0.8 \mathrm{kPa}$ to $22 \mathrm{kPa}$ during $80 \mathrm{~d}$ (one operation cycle), and cleaning of EDMF could efficiently reestablish TMP and biocidal actions for next filtration cycles. On the other hand, without dynamic membrane, the disinfection performance was reduced from the initial $\sim 100 \%$ log elimination (with no detectable live bacteria) to $\sim 44.4 \% \log$ decrease during $7 \mathrm{~d}$. Reactive oxygen species (ROS)-mediated oxidation was responsible for killing microorganisms in the EDMF, and - $\mathrm{OH}$ and $\mathrm{H}_{2} \mathrm{O}_{2}$ formed in this device had a key contribution, occasioning deterioration to cell envelopes and $\mathrm{K}^{+}$escape from the cytosol. Further, catalase and superoxide dismutase for intracellular ROS attenuation was inhibited, leading to the augmentation of intracellular oxidative stress and therefore high-efficient disinfection. Such findings underline the capacity of EDMF configuration to be

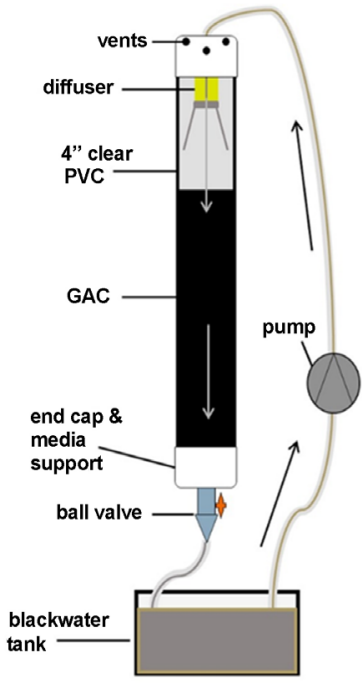

(A)

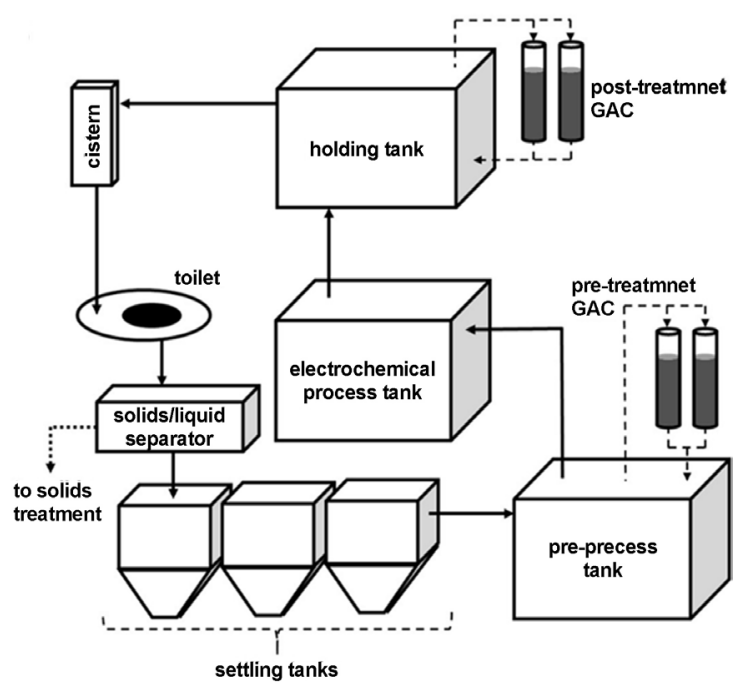

(B)

Figure 7. Experimental systems. (A) GAC packed bed column filter lab setup. (B) Schematic of GAC packed bed column filters integrated into the liquid treatment system [146]. 


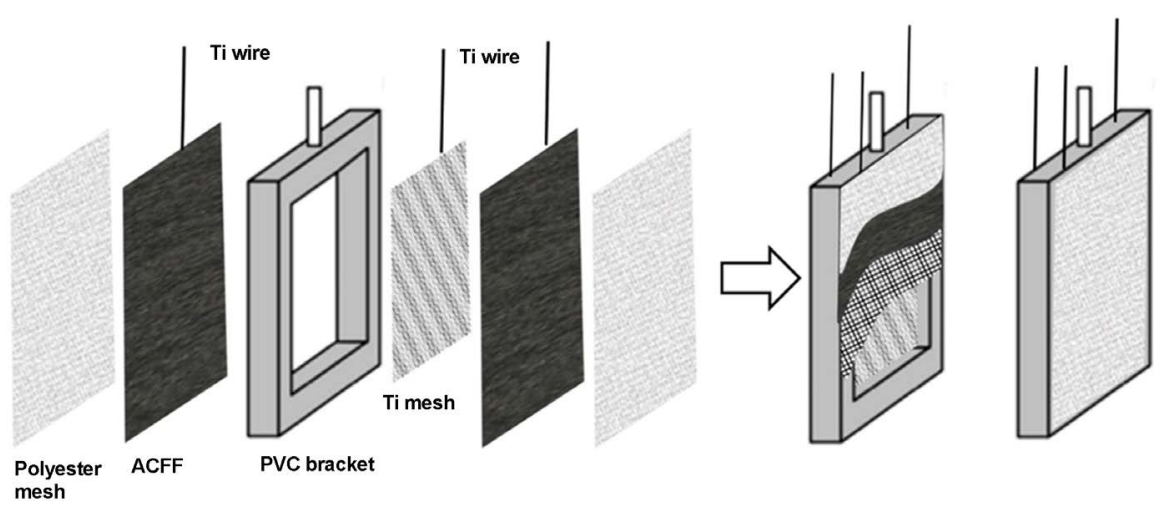

Figure 8. Schematic of the prepared EDMF module [147].
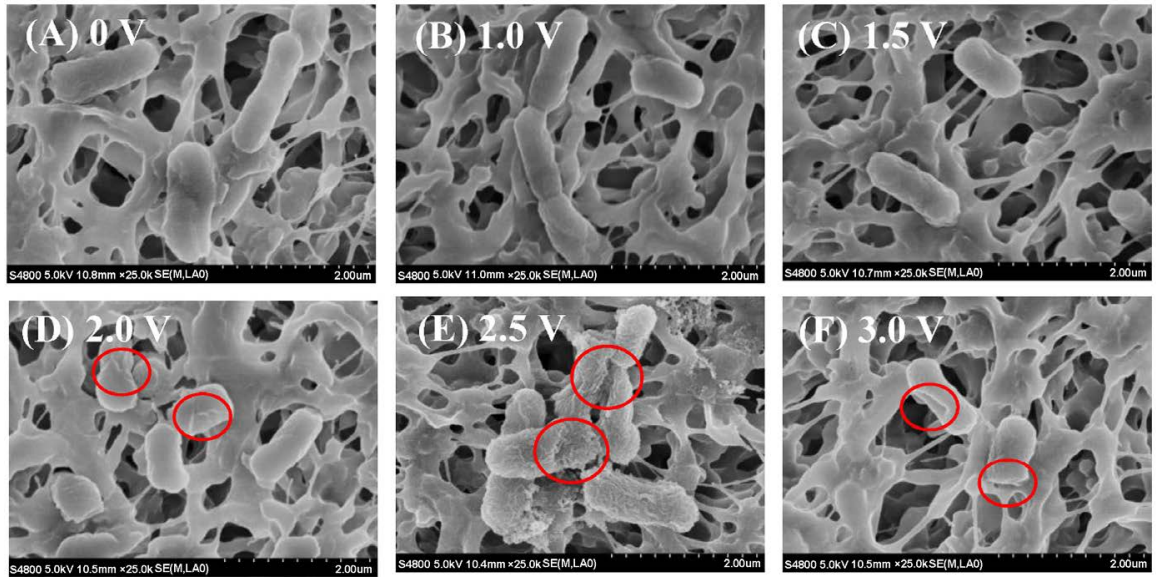

Figure 9. SEM images of E. coli after electrochemical treatment [147].

applied for treating and disinfecting wastewater.

Anfruns-Estrada et al. [148] suggested a sequential electrocoagulation (EC)/EF treatment (30 min each) as a more performant for a merged depollution and disinfection of urban wastewater.

\section{Conclusions}

From this work, the following conclusions can be drawn:

1) Restrictions like the need for acidic circumstance, sludge formation, and elevated chemical inputs have continued to retard the implementations of homogeneous Fenton in dealing with recalcitrant wastewater. Resolving such drawbacks stays, consequently, one of the significant research subjects in the domain of advanced oxidation processes for treating wastewater. This is obvious in the augmenting number of reports on procedures like heterogeneous Fenton oxidation, bio-electro-Fenton, fluidized-bed Fenton process, and homogeneous Fenton at circumneutral $\mathrm{pH}$ employing chelating chemicals. Between such procedures, heterogeneous Fenton remains the most largely tested thanks to the development in catalysis and material science. Fluidized-bed Fenton possesses the capacity to diminish sludge production and improve technique efficiency. A homogeneous Fenton process may be realized at circumneutral $\mathrm{pH}$ employing 
chelating chemicals. Nevertheless, because of numerous problems related to the injection of chelating products, homogeneous Fenton at circumneutral $\mathrm{pH}$ has not attracted as much interest. Electro-Fenton and bio-electro-Fenton techniques have the potential to diminish the price linked with the external introduction of $\mathrm{H}_{2} \mathrm{O}_{2}$ and decrease sludge formation. Heterogeneous Fenton and fluidized-bed Fenton methods seem to be the most realizable strategies to deal with the drawbacks of the Fenton reaction. On the other hand, features like price, ecological consequences, and upscaling possibility will decide their large-scale usability. This work has briefly discussed the fresh progress in dealing with the restrictions of the Fenton process. It will, consequently, besides the excellent review of Bello et al. [1], serve as a reference document in the domain of Fenton reaction for recalcitrant wastewater treatment, especially for specialists looking for improving the effectiveness of Fenton response.

2) The microbial electrolytic-Fenton cell was established as an encouraging substitutional option for disinfecting and treating water [132]. $\mathrm{H}_{2} \mathrm{O}_{2}$ was in situ formed in the cathode and reacted with $\mathrm{Fe}^{2+}$ chemicals to excite the Fenton response. Device efficiency was touched by the applied voltage, cathodic aeration rate and the levels of $\mathrm{Fe}^{2+}$ injection. Batch trials divulged that the applied voltage of $0.2 \mathrm{~V}$ was seen as more appropriate for total demobilization. Further, disinfection impacts were proportional to $\mathrm{Fe}^{2+}$ potion and aeration rate; however, following economic considerations, $0.3 \mathrm{mmol}\left(\mathrm{Fe}^{2+}\right) / \mathrm{mL}$ and $29.8 \mathrm{~mL} / \mathrm{min}$ aeration were adopted as optimal. As a prototype pathogenic microorganisms, E. coli hugely demobilized via the Fenton technology during which the bacteria cells were badly damaged through hydroxyl radical's aggression.

3) Despite the progress registered in the Fenton technologies, the classical process, and its ameliorated versions, membranes processes remain fundamental for secure wastewater treatment. As sure barriers towards pollution dispersal, processes such as nanofiltration should be coupled to Fenton techniques.

\section{Conflicts of Interest}

The authors declare no conflicts of interest regarding the publication of this paper.

\section{References}

[1] Bello, M.M., Abdul Raman, A.A. and Asghar, A. (2019) A Review on Approaches for Addressing the Limitations of Fentonoxidation for Recalcitrant Wastewater Treatment. Process Safety and Environmental Protection, 126, 119-140. https://doi.org/10.1016/j.psep.2019.03.028

[2] Ghernaout, D. (2017) Environmental Principles in the Holy Koran and the Sayings of the Prophet Muhammad. American Journal of Environmental Protection, 6, 75-79. https://doi.org/10.11648/j.ajep.20170603.13

[3] Ghernaout, D., Naceur, M.W. and Ghernaout, B. (2011) A Review of Electrocoagulation as a Promising Coagulation Process for Improved Organic and Inorganic Matters Removal by Electrophoresis and Electroflotation. Desalination and Water Treatment, 28, 287-320. https://doi.org/10.5004/dwt.2011.1493 
[4] Ghernaout, D. (2014) The Hydrophilic/Hydrophobic Ratio vs. Dissolved Organics Removal by Coagulation-A Review. Journal of King Saud University-Science, 26, 169-180. https://doi.org/10.1016/j.jksus.2013.09.005

[5] Ghernaout, D., Ghernaout, B. and Kellil, A. (2009) Natural Organic Matter Removal and Enhanced Coagulation as a Link between Coagulation and Electrocoagulation. Desalination and Water Treatment, 2, 203-222. https://doi.org/10.5004/dwt.2009.116

[6] Ghernaout, D. and Elboughdiri, N. (2019) Water Reuse: Emerging Contaminants Elimination-Progress and Trends. Open Access Library Journal, 6, e5981.

[7] Casas, E.M. and Bester, K. (2015) Can those Organic Micro-Pollutants That Are Recalcitrant in Activated Sludge Treatment Be Removed from Wastewater by Biofilm Reactors (Slow Sand Filters)? Science of the Total Environment, 506-507, 315-322. https://doi.org/10.1016/j.scitotenv.2014.10.113

[8] Mailler, R., Gasperi, J., Coquet, Y., Bulete, A., Vulliet, E., Deshayes, S., Zedek, S., Mirande-Bret, C., Eudes, V., Bressy, A., Caupos, E., Moilleron, R., Chebbo, G. and Rocher, V. (2015) Removal of a Wide Range of Emerging Pollutants from Wastewater Treatment Plant Discharges by Micro-Grain Activated Carbon in Fluidized Bed as Tertiary Treatment at Large Pilot Scale. Science of the Total Environment, 542, 983-996. https://doi.org/10.1016/j.scitotenv.2015.10.153

[9] Ghernaout, D., Elboughdiri, N. and Alghamdi, A. (2019) Direct Potable Reuse: The Singapore NEWater Project as a Role Model. Open Access Library Journal, 6, e5980. https://doi.org/10.4236/oalib.1105980

[10] Ghernaout, D. (2017) Water Reuse (WR): The Ultimate and Vital Solution for Water Supply Issues. International Journal of Sustainable Development Research, 3, 36-46. https://doi.org/10.11648/j.ijsdr.20170304.12

[11] Ghernaout, D., Elboughdiri, N. and Al Arni, S. (2019) Water Reuse (WR): Dares, Restrictions, and Trends. Applied Engineering, 3, 159-170.

[12] Ghernaout, D., Elboughdiri, N. and Ghareba, S. (2019) Drinking Water Reuse: One-Step Closer to Overpassing the "Yuck Factor". Open Access Library Journal, 6, e5895. https://doi.org/10.4236/oalib.1105895

[13] Ghernaout, D. (2018) Increasing Trends towards Drinking Water Reclamation from Treated Wastewater. World Journal of Applied Chemistry, 3, 1-9. https://doi.org/10.11648/j.wjac.20180301.11

[14] Perdigo, A., Petre, A., Rosal, R., Rodrı, A., Agu, A. and Ferna, A.R. (2010) Occurrence of Emerging Pollutants in Urban Wastewater and Their Removal through Biological Treatment Followed by Ozonation. Water Research, 44, 578-588. https://doi.org/10.1016/j.watres.2009.07.004

[15] Ghernaout, D. and Elboughdiri, N. (2019) Upgrading Wastewater Treatment Plant to Obtain Drinking Water. Open Access Library Journal, 6, e5959. https://doi.org/10.4236/oalib.1105959

[16] Ghernaout, D. and Elboughdiri, N. (2019) Iron Electrocoagulation Process for Disinfecting Water-A Review. Applied Engineering, 3, 154-158.

[17] Ghernaout, D. (2019) Disinfection via Electrocoagulation Process: Implied Mechanisms and Future Tendencies. EC Microbiology, 15, 79-90.

[18] Alalm, M.G., Tawfik, A. and Ookawara, S. (2015) Comparison of Solar $\mathrm{TiO}_{2}$ Photocatalysisand Solar Photo-Fenton for Treatment of Pesticides Industry Wastewater: Operational Conditions, Kinetics, and Costs. Journal of Water Process Engineering, 8, 55-63. https://doi.org/10.1016/j.jwpe.2015.09.007 
[19] Ghernaout, D. and Elboughdiri, N. (2019) Electrocoagulation Process Intensification for Disinfecting Water-A Review. Applied Engineering, 3, 140-147.

[20] Ghernaout, D. (2019) Greening Cold Fusion as an Energy Source for Water Treatment Distillation-A Perspective. American Journal of Quantum Chemistry and Molecular Spectroscopy, 3, 1-5.

[21] Ahmadi, M., Ramavandi, B. and Sahebi, S. (2019) Efficient Degradation of a Biorecalcitrant Pollutant from Wastewater Using a Fluidized Catalyst-Bed Reactor. Chemical Engineering Communications, 202, 1118-1129. https://doi.org/10.1080/00986445.2014.907567

[22] Ghernaout, D. (2019) Electrocoagulation Process for Microalgal Biotechnology-A Review. Applied Engineering, 3, 85-94.

[23] Bilinska, L., Gmurek, M. and Ledakowicz, S. (2016) Comparison between Industrial and Simulated Textile Wastewater Treatment by AOPs-Biodegradability, Toxicity and Cost Assessment. Chemical Engineering Journal, 306, 550-559. https://doi.org/10.1016/j.cej.2016.07.100

[24] Kellali, Y. and Ghernaout, D. (2019) Physicochemical and Algal Study of Three Dams (Algeria) and Removal of Microalgae by Enhanced Coagulation. Applied Engineering, 3, 56-64.

[25] Ghernaout, D. (2019) Reviviscence of Biological Wastewater Treatment-A Review. Applied Engineering, 3, 46-55.

[26] Ghernaout, D. (2013) Advanced Oxidation Phenomena in Electrocoagulation Process: A Myth or a Reality? Desalination and Water Treatment, 51, 7536-7554. https://doi.org/10.1080/19443994.2013.792520

[27] Ghernaout, D. (2019) Virus Removal by Electrocoagulation and Electrooxidation: New Findings and Future Trends. Journal of Environmental Science and Allied Research, 2019, 85-90.

[28] Ghernaout, D. (2019) Electrocoagulation and Electrooxidation for Disinfecting Water: New Breakthroughs and Implied Mechanisms. Applied Engineering, 3, 125133.

[29] Glaze, W.H., Kang, J.-H. and Chapin, D.H. (1987) The Chemistry of Water Treatment Processes Involving Ozone, Hydrogen Peroxide and Ultraviolet Radiation. Ozone: Science \& Engineering, 9, 335-352. https://doi.org/10.1080/01919518708552148

[30] Neyens, E. and Baeyens, J. (2003) A Review of Classic Fenton's Peroxidation as an Advanced Oxidation Technique. Journal of Hazardous Materials, 98, 33-50. https://doi.org/10.1016/S0304-3894(02)00282-0

[31] Tisa, F., Aziz, A.R.A. and Mohd, W.W.A. (2014) Basic Design of a Fluidized Bed Reactor for Wastewater Treatment Using Fenton Oxidation. International Journal of Innovation, Management and Technology, 5, 93-98. https://doi.org/10.7763/IJIMT.2014.V5.493

[32] Chong, M.N., Jin, B., Chow, C.W.K. and Saint, C. (2014) Recent Developments in Photocatalytic Water Treatment Technology: A Review. Water Research, 44, 2997 3027. https://doi.org/10.1016/j.watres.2010.02.039

[33] Gągol, M., Przyjazny, A. and Boczkaj, G. (2018) Wastewater Treatment by Means of Advanced Oxidation Processes Based on Cavitation-A Review. Chemical Engineering Journal, 338, 599-627. https://doi.org/10.1016/j.cej.2018.01.049

[34] Moreira, F.C., Boaventura, R.A.R., Brillas, E. and Vilar, V.J.P. (2017) Electrochemical Advanced Oxidation Processes: A Review on Their Application to Synthetic and 
Real Wastewaters. Applied Catalysis B: Environmental, 202, 217-261. https://doi.org/10.1016/j.apcatb.2016.08.037

[35] Irki, S., Ghernaout, D., Naceur, M.W., Alghamdi, A. and Aichouni, M. (2018) Decolorizing Methyl Orange by Fe-Electrocoagulation Process-A Mechanistic Insight. International Journal of Environmental Chemistry, 2, 18-28. https://doi.org/10.11648/j.ijec.20180201.14

[36] Ghernaout, D. and Elboughdiri, N. (2019) Mechanistic Insight into Disinfection Using Ferrate(VI). Open Access Library Journal, 6, e5946.

[37] Ghernaout, D. and Elboughdiri, N. (2019) Water Disinfection: Ferrate(VI) as the Greenest Chemical-A Review. Applied Engineering, 3, 171-180.

[38] Munoz, M., de Pedro, Z.M., Casas, J.A. and Rodriguez, J.J. (2019) Preparation of Magnetite-Based Catalysts and Their Application in Heterogeneous Fenton Oxidation-A Review. Applied Catalysis B: Environmental, 176-177, 249-265. https://doi.org/10.1016/j.apcatb.2015.04.003

[39] Huang, C.P., Dong, C. and Tang, Z. (1993) Advanced Chemical Oxidation: Its Present Role and Potential Future in Hazardous Waste Treatment. Waste Management, 13, 361-377. https://doi.org/10.1016/0956-053X(93)90070-D

[40] Ghernaout, D. and Naceur, M.W. (2011) Ferrate(VI): In Situ Generation and Water Treatment-A Review. Desalination and Water Treatment, 30, 319-332. https://doi.org/10.5004/dwt.2011.2217

[41] Nidheesh, P.V. and Rajan, R. (2016) Removal of Rhodamine B from a Water Medium Using Hydroxyl and Sulphate Radicals Generated by Iron Loaded Activated Carbon. RSC Advances, 6, 5330-5340. https://doi.org/10.1039/C5RA19987E

[42] Xavier, S., Gandhimathi, R., Nidheesh, P.V. and Ramesh, S.T. (2015) Comparison of Homogeneous and Heterogeneous Fenton Processes for the Removal of Reactive Dye Magenta MB from Aqueous Solution. Desalination and Water Treatment, 53, 109-118. https://doi.org/10.1080/19443994.2013.844083

[43] Alalm, M.G., Tawfik, A. and Ookawara, S. (2015) Degradation of Four Pharmaceuticals by Solar Photo-Fenton Process: Kinetics and Costs Estimation. Journal of Environmental Chemical Engineering, 3, 46-51. https://doi.org/10.1016/j.jece.2014.12.009

[44] Mackul'ak, T., Mosný, M., Grabic, R., Golovko, O., Koba, O. and Birošová, L. (2015) Fenton-Like Reaction: A Possible Way to Efficiently Remove Illicit Drugs and Pharmaceuticals from Wastewater. Environmental Toxicology and Pharmacology, 39, 483-488. https://doi.org/10.1016/j.etap.2014.12.016

[45] Aytar, P., Gedikli, S., Sam, M., Farizoğlu, B. and Çabuk, A. (2015) Sequential Treatment of Olive Oil Mill Wastewater with Adsorption and Biological and Photo-Fenton Oxidation. Environmental Science and Pollution Research, 20, 3060-3067. https://doi.org/10.1007/s11356-012-1212-6

[46] Justino, C., Marques, A.G., Duarte, K.R., Duarte, A.C., Pereira, R., Rocha-Santos, T. and Freitas, A.C. (2010) Degradation of Phenols in Olive Oil Mill Wastewater by Biological, Enzymatic, and Photo-Fenton Oxidation. Environmental Science and Pollution Research, 17, 650-656. https://doi.org/10.1007/s11356-009-0256-8

[47] Laiju, A.R., Sivasankar, T. and Nidheesh, P.V. (2014) Iron-Loaded Mangosteen as a Heterogeneous Fenton Catalyst for the Treatment of Landfill Leachate. Environmental Science and Pollution Research, 21, 10900-10907. https://doi.org/10.1007/s11356-014-2883-y

[48] Navarro, S., Fenoll, J., Vela, N., Ruiz, E. and Navarro, G. (2011) Removal of Ten Pesticides from Leaching Water at Pilot Plant Scale by Photo-Fenton Treatment. 
Chemical Engineering Journal, 167, 42-49. https://doi.org/10.1016/j.cej.2010.11.105

[49] Saini, R., Raghunath, C.V., Pandey, P. and Kumar, P. (2016) Optimization of Fenton Oxidation for the Removal of Methyl Parathion in Aqueous Solution. Perspectives in Science, 1980, 670-672. https://doi.org/10.1016/j.pisc.2016.06.054

[50] Tony, M.A., Zhao, Y.Q. and Tayeb, A.M. (2009) Exploitation of Fenton and Fenton-Like Reagents as Alternative Conditioners for Alum Sludge Conditioning. Journal of Environmental Sciences, 21, 101-105. https://doi.org/10.1016/S1001-0742(09)60018-8

[51] Yu, W., Yang, J., Shi, Y., Song, J., Shi, Y., Xiao, J., Li, C., Xu, X., He, S., Liang, S., $\mathrm{Wu}, \mathrm{X}$. and $\mathrm{Hu}, \mathrm{J}$. (2016) Roles of Iron Species and pH Optimization on Sewage Sludge Conditioning with Fenton's Reagent and Lime. Water Research, 95, 124-133. https://doi.org/10.1016/j.watres.2016.03.016

[52] Ghernaout, D. (2017) The Holy Koran Revelation: Iron Is a "Sent Down" Metal. American Journal of Environmental Protection, 6, 101-104. https://doi.org/10.11648/j.ajep.20170604.14

[53] Ghernaout, D., Moulay, S., AitMessaoudene, N., Aichouni, M., Naceur, M.W. and Boucherit, A. (2014) Coagulation and Chlorination of NOM and Algae in Water Treatment: A Review. International Journal of Environmental Monitoring and Analysis, 2, 23-34. https://doi.org/10.11648/j.ijema.s.2014020601.14

[54] Ghernaout, D., Al-Ghonamy, A.I., Boucherit, A., Ghernaout, B., Naceur, M.W., AitMessaoudene, N., Aichouni, M., Mahjoubi, A.A. and Elboughdiri, N.A. (2015) Brownian Motion and Coagulation Process. American Journal of Environmental Protection, 4, 1-15. https://doi.org/10.11648/j.ajeps.s.2015040501.11

[55] Ghernaout, D., Al-Ghonamy, A.I., Naceur, M.W., Boucherit, A., Messaoudene, N.A., Aichouni, M., Mahjoubi, A.A. and Elboughdiri, N.A. (2015) Controlling Coagulation Process: From Zeta Potential to Streaming Potential. American Journal of Environmental Protection, 4, 16-27. https://doi.org/10.11648/j.ajeps.s.2015040501.12

[56] Ghernaout, D. and Boucherit, A. (2015) Review of Coagulation's Rapid Mixing for NOM Removal. Journal of Research \& Developments in Chemistry, 2015, Article ID: 926518. https://doi.org/10.5171/2015.926518

[57] Muangthai, I., Ratanatamsakul, C. and Lu, M. (2010) Removal of 2,4-Dichlorophenol by Fluidized-Bed Fenton Process. Sustainable Environment Research, 20, 325-331.

[58] Ghernaout, D. and Ghernaout, B. (2012) Sweep Flocculation as a Second Form of Charge Neutralisation-A Review. Desalination and Water Treatment, 44, 15-28. https://doi.org/10.1080/19443994.2012.691699

[59] Pouran, S.R., Abdul Aziz, A.R. and Wan Daud, W.M.A. (2015) Review on the Main Advances in Photo-Fenton Oxidation System for Recalcitrant Wastewaters. Journal of Industrial and Engineering Chemistry, 21, 53-69. https://doi.org/10.1016/j.jiec.2014.05.005

[60] Villegas-Guzman, P., Giannakis, S., Rtimi, S., Grandjean, D., Bensimon, M., de Alencastro, L.F., Torres-Palma, R. and Pulgarin, C. (2017) A Green Solar PhotoFenton Process for the Elimination of Bacteria and Micropollutants in Municipal Wastewater Treatment Using Mineral Iron and Natural Organic Acids. Applied Catalysis B: Environmental, 219, 538-549. https://doi.org/10.1016/j.apcatb.2017.07.066

[61] Villegas-Guzman, P., Giannakis, S., Torres-Palma, R.A. and Pulgarin, C. (2017) Remarkable Enhancement of Bacterial Inactivation in Wastewater through Promo- 
tion of Solar Photo-Fenton at Near-Neutral pH by Natural Organic Acids. Applied Catalysis B: Environmental, 205, 219-227.

https://doi.org/10.1016/j.apcatb.2016.12.021

[62] Clarizia, L., Russo, D., Di Somma, I., Marotta, R. and Andreozzi, R. (2017) Homogeneous Photo-Fenton Processes at Near Neutral pH: A Review. Applied Catalysis B: Environmental, 209, 358-371. https://doi.org/10.1016/j.apcatb.2017.03.011

[63] Pliego, G., Zazo, J.A., Garcia-Muñoz, P., Munoz, M., Casas, J.A. and Rodriguez, J.J. (2015) Trends in the Intensification of the Fenton Process for Wastewater Treatment-An Overview. Critical Reviews in Environmental Science and Technology, 45, 2611-2692. https://doi.org/10.1080/10643389.2015.1025646

[64] Tuesta, J.L.D., De García-Figueruelo, C., Quintanilla, A., Casas, J.A. and Rodriguez, J.J. (2015) Application of High-Temperature Fenton Oxidation for the Treatment of Sulfonation Plant Wastewater. Journal of Chemical Technology \& Biotechnology, 90, 1839-1846. https://doi.org/10.1002/jctb.4494

[65] Park, J., Wang, J.J., Xiao, R., Tafti, N., Delaune, R.D. and Seo, D. (2018) Degradation of Orange $\mathrm{G}$ by Fenton-Like Reaction with Fe-Impregnated Biochar Catalyst. Bioresource Technology, 249, 368-376. https://doi.org/10.1016/j.biortech.2017.10.030

[66] Qin, J., Lin, C., Almebayedh, H. and Albader, M. (2019) Decomposition of LongChain Petroleum Hydrocarbons by Fenton-Like Processes: Effects of Ferrous Iron Source, Salinity and Temperature. Ecotoxicology and Environmental Safety, 169, 764-769. https://doi.org/10.1016/j.ecoenv.2018.11.086

[67] Zazo, J.A., Pliego, G., Blasco, S., Casas, J.A. and Rodriguez, J.J. (2011) Intensification of the Fenton Process by Increasing the Temperature. Industrial \& Engineering Chemistry Research, 50, 866-870. https://doi.org/10.1021/ie101963k

[68] Manenti, D.R., Soares, P.A., Silva, T.F.C.V., Módenes, A.N., Espinoza-Quiñones, F.R., Bergamasco, R., Boaventura, R.A.R. and Vilar, V.J.P. (2015) Performance Evaluation of Different Solar Advanced Oxidation Processes Applied to the Treatment of a Real Textile Dyeing Wastewater. Environmental Science and Pollution Research, 22, 833-845. https://doi.org/10.1007/s11356-014-2767-1

[69] Guo, S., Yuan, N., Zhang, G. and Yu, J.C. (2017) Graphene Modified Iron Sludge Derived from Homogeneous Fenton Process as an Efficient Heterogeneous Fenton Catalyst for Degradation of Organic Pollutants. Microporous and Mesoporous Materials, 238, 62-68. https://doi.org/10.1016/j.micromeso.2016.02.033

[70] Dias, F.F., Oliveira, A.A.S., Arcanjo, A.P., Moura, F.C.C. and Pacheco, J.G.A. (2017) Residue-Based Iron Catalyst for the Degradation of Textile Dye via Heterogeneous Photo-Fenton. Applied Catalysis B: Environmental, 186, 136-142. https://doi.org/10.1016/j.apcatb.2015.12.049

[71] Liu, Y., Zhang, G., Fang, S., Chong, S. and Zhu, J. (2016) Degradation of Aniline by Heterogeneous Fenton's Reaction Using a Ni-Fe Oxalate Complex Catalyst. Journal of Environmental Management, 182, 367-373. https://doi.org/10.1016/j.jenvman.2016.07.084

[72] Bello, M.M., Abdul Raman, A.A. and Purushothaman, M. (2017) Applications of Fluidized Bed Reactor in Wastewater Treatment-A Review of the Major Design and Operational Parameters. Journal of Cleaner Production, 141, 1492-1514. https://doi.org/10.1016/j.jclepro.2016.09.148

[73] Davarnejad, R. and Azizi, J. (2016) Alcoholic Wastewater Treatment Using Electro-Fenton Technique Modified by $\mathrm{Fe}_{2} \mathrm{O}_{3}$ Nanoparticles. Journal of Environmental Chemical Engineering, 4, 2342-2349. https://doi.org/10.1016/j.jece.2016.04.009 
[74] Oturan, M.A. and Aaron, J.J. (2014) Advanced Oxidation Processes in Water/ Wastewater Treatment: Principles and Applications: A Review. Critical Reviews in Environmental Science and Technology, 44, 2577-2641. https://doi.org/10.1080/10643389.2013.829765

[75] Pignatello, J.J., Oliveros, E. and MacKay, A. (2006) Advanced Oxidation Processes for Organic Contaminant Destruction Based on the Fenton Reaction and Related Chemistry. Critical Reviews in Environmental Science and Technology, 36, 1-84. https://doi.org/10.1080/10643380500326564

[76] Valero, P., Verbel, M., Silva-Agredo, J., Mosteo, R., Ormad, M.P. and Torres-Palma, R.A. (2017) Electrochemical Advanced Oxidation Processes for Staphylococcus aureus Disinfection in Municipal WWTP Effluents. Journal of Environmental Management, 198, 256-265. https://doi.org/10.1016/j.jenvman.2017.04.070

[77] Wang, N., Zheng, T., Zhang, G. and Wang, P. (2016) A Review on Fenton-Like Processes for Organic Wastewater Treatment. Journal of Environmental Chemical Engineering, 4, 762-787. https://doi.org/10.1016/j.jece.2015.12.016

[78] Wang, Y., Feng, C., Li, Y., Gao, J. and Yu, C.-P. (2016) Enhancement of Emerging Contaminants Removal Using Fenton Reaction Driven by $\mathrm{H}_{2} \mathrm{O}_{2}$-Producing Microbial Fuel Cells. Chemical Engineering Journal, 307, 679-686. https://doi.org/10.1016/j.cej.2016.08.094

[79] Brillas, E., Sirés, I. and Oturan, M.A. (2009) Electro-Fenton Process and Related Electro-Chemical Technologies Based on Fenton's Reaction Chemistry. Chemical Reviews, 109, 6570-6631. https://doi.org/10.1021/cr900136g

[80] Poza-Nogueiras, V., Rosales, E., Pazos, M. and Sanroman, M.A. (2018) Current Advances and Trends in Electro-Fenton Process Using Heterogeneous Catalysts-A Review. Chemosphere, 201, 399-416. https://doi.org/10.1016/j.chemosphere.2018.03.002

[81] Ganiyu, S.O., Zhou, M. and Martínez-Huitle, C.A. (2018) Heterogeneous Electro-Fenton and Photoelectro-Fenton Processes: A Critical Review of Fundamental Principles and Application for Water/Wastewater Treatment. Applied Catalysis B: Environmental, 235, 103-129. https://doi.org/10.1016/j.apcatb.2018.04.044

[82] Li, A.L., Hu, H., Teng, X., Yu, Y., Zhu, Y. and Su, X. (2018) Electrogeneration of $\mathrm{H}_{2} \mathrm{O}_{2}$ Using a Porous Hydrophobic Acetylene Black Cathode for Electro-Fenton Process. Chemical Engineering and Processing. Process Intensification, 133, 34-39. https://doi.org/10.1016/j.cep.2018.09.013

[83] Li, B.X., Chen, S., Angelidaki, I. and Zhang, Y. (2018) Bio-Electro-Fenton Processes for Wastewater Treatment: Advances and Prospects. Chemical Engineering Journal, 354, 492-506. https://doi.org/10.1016/j.cej.2018.08.052

[84] Usman, M., Hanna, K. and Haderlein, S. (2016) Fenton Oxidation to Remediate PAHs in Contaminated Soils: A Critical Review of Major Limitations and Counter-Strategies. Science of the Total Environment, 569-570, 179-190. https://doi.org/10.1016/j.scitotenv.2016.06.135

[85] Barros, W.R.P., Steter, J.R., Lanza, M.R.V. and Tavares, A.C. (2016) Catalytic Activity of $\mathrm{Fe}_{3-\mathrm{x}} \mathrm{Cu}_{\mathrm{x}} \mathrm{O}_{4}(0 \leq \mathrm{x} \leq 0.25)$ Nanoparticles for the Degradation of Amaranth Food Dye by Heterogeneous Electro-Fenton Process. Applied Catalysis B: Environmental, 180, 434-441. https://doi.org/10.1016/j.apcatb.2015.06.048

[86] Martínez-Huitle, C.A. and Brillas, E. (2016) Decontamination of Wastewaters Containing Synthetic Organic Dyes by Electrochemical Methods: A General Review. Applied Catalysis B: Environmental, 87, 105-145. https://doi.org/10.1016/j.apcatb.2008.09.017 
[87] Amorim, C.C., Leão, M.M.D., Moreira, R.F.P.M., Fabris, J.D. and Henriques, A.B. (2013) Performance of Blast Furnace Waste for Azo Dye Degradation through Photo-Fenton-Like Processes. Chemical Engineering Journal, 224, 59-66. https://doi.org/10.1016/j.cej.2013.01.053

[88] Tang, W.Z. and Huang, C.P. (1996) 2,4-Dichlorophenol Oxidation Kinetics by Fenton's Reagent. Environmental Technology, 17, 1371-1378. https://doi.org/10.1080/09593330.1996.9618465

[89] Shemer, H., Kunukcu, Y.K. and Linden, K.G. (2006) Degradation of the Pharmaceutical Metronidazole via UV, Fenton and Photo-Fenton Processes. Chemosphere, 63, 269-276. https://doi.org/10.1016/j.chemosphere.2005.07.029

[90] Acisli, O., Khataee, A., Darvishi Cheshmeh Soltani, R. and Karaca, S. (2017) Ultrasound-Assisted Fenton Process Using Siderite Nanoparticles Prepared via Planetary Ball Milling for Removal of Reactive Yellow 81 in Aqueous Phase. Ultrasonics Sonochemistry, 35, 210-218. https://doi.org/10.1016/j.ultsonch.2016.09.020

[91] Pignatello, J.J. (1992) Dark and Photoassistediron(3+)-Catalyzed Degradation of Chlorophenoxy Herbicides by Hydrogen Peroxide. Environmental Science \& Technology, 26, 944-951. https://doi.org/10.1021/es00029a012

[92] Kim, S.-M. and Vogelpohl, A. (1998) Degradation of Organic Pollutants by the Photo-Fenton-Process. Chemical Engineering \& Technology, 21, 187-191. https://doi.org/10.1002/(SICI)1521-4125(199802)21:2<187::AID-CEAT187>3.0.CO; $\underline{2-\mathrm{H}}$

[93] Chen, C.-Y., Wu, P.-S. and Chung, Y.-C. (2009) Coupled Biological and Photo-Fenton Pre-Treatment System for the Removal of Di-(2-ethylhexyl) Phthalate (DEHP) from Water. Bioresource Technology, 100, 4531-4534.

https://doi.org/10.1016/j.biortech.2009.04.020

[94] Ma, J., Yang, Q., Wen, Y. and Liu, W. (2017) Fe-g- $\mathrm{C}_{3} \mathrm{~N}_{4} /$ Graphitized Mesoporous Carbon Composite as an Effective Fenton-Like Catalyst in a Wide pH Range. $A p$ plied Catalysis B: Environmental, 201, 232-240. https://doi.org/10.1016/j.apcatb.2016.08.048

[95] Garcia-Segura, S., Bellotindos, L.M., Huang, Y.-H., Brillas, E. and Lu, M.-C. (2016) Fluidized-Bed Fenton Process as Alternative Wastewater Treatment Technology-A Review. Journal of the Taiwan Institute of Chemical Engineers, 67, 211-225. https://doi.org/10.1016/j.jtice.2016.07.021

[96] Lima, M.J., Silva, C.G., Silva, A.M.T., Lopes, J.C.B., Dias, M.M. and Faria, J.L. (2017) Homogeneous and Heterogeneous Photo-Fenton Degradation of Antibiotics Using an Innovative Static Mixer Photoreactor. Chemical Engineering Journal, 310, 342351. https://doi.org/10.1016/j.cej.2016.04.032

[97] Asghar, A., Raman, A.A.A. and Daud, W.M.A.W. (2015) Advanced Oxidation Processes for In-Situ Production of Hydrogen Peroxide/Hydroxyl Radical for Textile Wastewater Treatment: A Review. Journal of Cleaner Production, 87, 826-838. https://doi.org/10.1016/j.jclepro.2014.09.010

[98] Chen, T.-C., Matira, E.M., Lu, M.-C. and Dalida, M.L.P. (2016) Degradation of Dimethylsulfoxide through Fluidized-Bed Fenton Process. International Journal of Environmental Science and Technology, 300, 218-226.

[99] Chakma, S. and Moholkar, V.S. (2013) Physical Mechanism of Sono-Fenton Process. AIChE Journal, 59, 4303-4313. https://doi.org/10.1002/aic.14150

[100] Chou, S. and Huang, C. (1999) Application of a Supported Iron Oxyhydroxide Catalyst in Oxidation of Benzoic Acid by Hydrogen Peroxide. Chemosphere, 38, 27192731. https://doi.org/10.1016/S0045-6535(98)00474-3 
[101] Huang, C.P. and Huang, Y.H. (2009) Application of an Active Immobilized Iron Oxide with Catalytic $\mathrm{H}_{2} \mathrm{O}_{2}$ for the Mineralization of Phenol in a Batch Photo-Fluidized Bed Reactor. Applied Catalysis A: General, 357, 135-141. https://doi.org/10.1016/j.apcata.2008.12.043

[102] Huang, Y.F. and Huang, Y.H. (2009) Behavioral Evidence of the Dominant Radicals and Intermediates Involved in Bisphenol A Degradation Using an Efficient $\mathrm{Co}_{2}{ }^{+} /$ PMS Oxidation Process. Journal of Hazardous Materials, 167, 418-426. https://doi.org/10.1016/j.jhazmat.2008.12.138

[103] Anotai, J., Sakulkittimasak, P., Boonrattanakij, N. and Lu, M. (2009) Kinetics of Nitrobenzene Oxidation and Iron Crystallization in Fluidized-Bed Fenton Process. Journal of Hazardous Materials, 165, 874-880. https://doi.org/10.1016/j.jhazmat.2008.10.062

[104] Aghdasinia, H., Bagheri, R., Vahid, B. and Khataee, A. (2016) Central Composite Design Optimization of Pilot Plant Fluidized-Bed Heterogeneous Fenton Process for Degradation of an Azo Dye. Environmental Technology (United Kingdom), 37, 2703-2712. https://doi.org/10.1080/09593330.2016.1159734

[105] Mita, L., Grumiro, L., Rossi, S., Bianco, C., Defez, R., Gallo, P., Mita, D.G. and Diano, N. (2015) Bisphenol A Removal by a Pseudomonas aeruginosa Immobilized on Granular Activated Carbon and Operating in a Fluidized Bed Reactor. Journal of Hazardous Materials, 291, 129-135. https://doi.org/10.1016/j.jhazmat.2015.02.072

[106] Cheng, H., Chou, S., Chen, S. and Yu, C. (2014) Photoassisted Fenton Degradation of Phthalocyanine Dyes from Wastewater of Printing Industry Using $\mathrm{Fe}(\mathrm{II}) / \gamma-\mathrm{Al}_{2} \mathrm{O}_{3}$ Catalyst in Up-Flow Fluidized-Bed. Journal of Environmental Sciences, 26, 13071312. https://doi.org/10.1016/S1001-0742(13)60604-X

[107] Huang, C.P. and Chu, C. (2012) Indirect Electrochemical Oxidation of Chlorophenols in Dilute Aqueous Indirect Electrochemical Oxidation of Chlorophenols in Dilute aqueous Solutions. Journal of Environmental Engineering, 138, 375-385. https://doi.org/10.1061/(ASCE)EE.1943-7870.0000518

[108] Logan, B.E., Murano, C., Scott, K., Gray, N.D. and Head, I.M. (2005) Electricity Generation from Cysteine in a Microbial Fuel Cell. Water Research, 39, 942-952. https://doi.org/10.1016/j.watres.2004.11.019

[109] Wang, H. and Ren, Z.J. (2013) A Comprehensive Review of Microbial Electrochemical Systems as a Platform Technology. Biotechnology Advances, 31, 1796-1807. https://doi.org/10.1016/j.biotechadv.2013.10.001

[110] Mai, H. and Li, X. (2013) Bio-Electro-Fenton Process Driven by Microbial Fuel Cell for Wastewater Treatment. Environmental Science \& Technology, 44, 1875-1880. https://doi.org/10.1021/es9032925

[111] Zhu, X. and Ni, J. (2009) Simultaneous Processes of Electricity Generation and p-Nitrophenol Degradation in a Microbial Fuel Cell. Electrochemistry Communications, 11, 274-277. https://doi.org/10.1016/j.elecom.2008.11.023

[112] Feng, C., Li, F., Liu, H., Lang, X. and Fan, S. (2010) A Dual-Chamber Microbial Fuel Cell with Conductive Film-Modified Anode and Cathode and Its Application for the Neutral Electro-Fenton Process. Electrochimica Acta, 55, 2048-2054. https://doi.org/10.1016/j.electacta.2009.11.033

[113] Zhu, X. and Logan, B.E. (2013) Using Single-Chamber Microbial Fuel Cells as Renewable Power Sources of Electro-Fenton Reactors for Organic Pollutant Treatment. Journal of Hazardous Materials, 252-253, 198-203. https://doi.org/10.1016/j.jhazmat.2013.02.051

[114] Li, B.X., Jin, X., Zhao, N., Angelidaki, I. and Zhang, Y. (2017) Novel Bio-Electro- 
Fenton Technology for Azo Dye Wastewater Treatment Using Microbial ReverseElectrodialysis Electrolysis Cell. Bioresource Technology, 228, 322-329. https://doi.org/10.1016/j.biortech.2016.12.114

[115] Zhang, L., Yin, X., Fong, S. and Li, Y. (2015) Bio-Electrochemical Degradation of Paracetamol in a Microbial Fuel Cell-Fenton System. Chemical Engineering Journal, 276, 185-192. https://doi.org/10.1016/j.cej.2015.04.065

[116] Asghar, A., Raman, A.A.A. and Daud, W.M.A.W. (2017) In Situ Production of Hydrogen Peroxide in a Microbial Fuel Cell for Recalcitrant Wastewater Treatment. Journal of Chemical Technology \& Biotechnology, 92, 1825-1840. https://doi.org/10.1002/jctb.5192

[117] Perazzolo, V., Durante, C., Pilot, R., Paduano, A., Zheng, J., Rizzi, G.A., Martucci, A., Granozzi, G. and Gennaro, A. (2015) Nitrogen and Sulfur Doped Mesoporous Carbon as Metal-Free Electrocatalysts for the in Situ Production of Hydrogen Peroxide. Carbon, 95, 949-963. https://doi.org/10.1016/j.carbon.2015.09.002

[118] Asghar, A., Raman, A.A.A., Daud, W.M.A.W., Ahmad, M. and Zain, S.U.B.M. (2017) Effect of Nitrogen Doping on Graphite Cathode for Hydrogen Peroxide Production and Power Generation in MFC. Journal of the Taiwan Institute of Chemical Engineers, 76, 89-100. https://doi.org/10.1016/j.jtice.2017.04.016

[119] Fellinger, T.P., Hasché, F., Strasser, P. and Antonietti, M. (2012) Mesoporous Nitrogen-Doped Carbon for the Electrocatalytic Synthesis of Hydrogen Peroxide. Journal of the American Chemical Society, 134, 4072-4075. https://doi.org/10.1021/ja300038p

[120] Wang, D., Hou, H., Hu, J., Xu, J., Huang, L., Hu, S., Liang, S., Xiao, K., Liu, B. and Yang, J. (2019) A Bio-Electro-Fenton System with a Facile Anti-Biofouling Air Cathode for Efficient Degradation of Landfill Leachate. Chemosphere, 215, 173-181. https://doi.org/10.1016/j.chemosphere.2018.10.018

[121] Ghernaout, D., Alshammari, Y., Alghamdi, A., Aichouni, M., Touahmia, M. and AitMessaoudene, N. (2018) Water Reuse: Extenuating Membrane Fouling in Membrane Processes. International Journal of Environmental Chemistry, 2, 1-12. https://doi.org/10.11648/j.ajche.20180602.12

[122] AitMessaoudene, N., Naceur, M.W., Ghernaout, D., Alghamdi, A. and Aichouni, M. (2018) On the Validation Perspectives of the Proposed Novel Dimensionless Fouling Index. International Journal of Advanced and Applied Sciences, 5, 116-122. https://doi.org/10.21833/ijaas.2018.07.014

[123] Ren, G., Zhou, M., Su, P., Yang, W., Lu, X. and Zhang, Y. (2018) Simultaneous Sulfadiazines Degradation and Disinfection from Municipal Secondary Effluent by a Flow-Through Electro-Fenton Process with Graphene Modified Cathode. Journal of Hazardous Materials, 368, 830-839. https://doi.org/10.1016/j.jhazmat.2019.01.109

[124] Ghernaout, D., Aichouni, M. and Touahmia, M. (2019) Mechanistic Insight into Disinfection by Electrocoagulation-A Review. Desalination and Water Treatment, 141, 68-81. https://doi.org/10.5004/dwt.2019.23457

[125] Ghernaout, D., Touahmia, M. and Aichouni, M. (2019) Disinfecting Water: Electrocoagulation as an Efficient Process. Applied Engineering, 3, 1-12.

[126] Ghernaout, D., Alghamdi, A., Aichouni, M. and Touahmia, M. (2018) The Lethal Water Tri-Therapy: Chlorine, Alum, and Polyelectrolyte. World Journal of Applied Chemistry, 3, 65-71. https://doi.org/10.11648/j.wjac.20180302.14

[127] Ghernaout, D., Naceur, M.W. and Aouabed, A. (2011) On the Dependence of Chlorine By-Products Generated Species Formation of the Electrode Material and Applied Charge during Electrochemical Water Treatment. Desalination, 270, 9-22. 
https://doi.org/10.1016/j.desal.2011.01.010

[128] Boucherit, A., Moulay, S., Ghernaout, D., Al-Ghonamy, A.I., Ghernaout, B., Naceur, M.W., AitMessaoudene, N., Aichouni, M., Mahjoubi, A.A. and Elboughdiri, N.A. (2015) New Trends in Disinfection By-Products Formation upon Water Treatment. Journal of Research \& Developments in Chemistry, 2015, Article ID: 628833. https://doi.org/10.5171/2015.628833

[129] Ghernaout, D. (2018) Disinfection and DBPs Removal in Drinking Water Treatment: A Perspective for a Green Technology. International Journal of Advanced and Applied Sciences, 5, 108-117. https://doi.org/10.21833/ijaas.2018.02.018

[130] Ghernaout, D. (2019) Greening Electrocoagulation Process for Disinfecting Water. Applied Engineering, 3, 27-31.

[131] Ghernaout, D. (2017) Water Treatment Chlorination: An Updated Mechanistic Insight Review. Chemistry Research Journal, 2, 125-138.

[132] Zhou, S., Huang, S., Li, X., Angelidaki, I. and Zhang, Y. (2018) Microbial Electrolytic Disinfection Process for Highly Efficient Escherichia coli Inactivation. Chemical Engineering Journal, 342, 220-227. https://doi.org/10.1016/j.cej.2018.02.090

[133] Ghernaout, D., Badis, A., Ghernaout, B. and Kellil, A. (2008) Application of Electrocoagulation in Escherichia coli Culture and Two Surface Waters. Desalination, 219, 118-125. https://doi.org/10.1016/j.desal.2007.05.010

[134] Ghernaout, D. (2017) Microorganisms' Electrochemical Disinfection Phenomena. EC Microbiology, 9, 160-169.

[135] Ghernaout, D., Alghamdi, A. and Ghernaout, B. (2019) Microorganisms' Killing: Chemical Disinfection vs. Electrodisinfection. Applied Engineering, 3, 13-19.

[136] Ghernaout, D. and Ghernaout, B. (2010) From Chemical Disinfection to Electrodisinfection: The Obligatory Itinerary? Desalination and Water Treatment, 16, 156-175. https://doi.org/10.5004/dwt.2010.1085

[137] Belhout, D., Ghernaout, D., Djezzar-Douakh, S. and Kellil, A. (2010) Electrocoagulation of a Raw Water of Ghrib Dam (Algeria) in Batch Using Iron Electrodes. Desalination and Water Treatment, 16, 1-9. https://doi.org/10.5004/dwt.2010.1081

[138] Ghernaout, D., Ghernaout, B. and Naceur, M.W. (2011) Embodying the Chemical Water Treatment in the Green Chemistry-A Review. Desalination, 271, 1-10. https://doi.org/10.1016/j.desal.2011.01.032

[139] Ghernaout, D., Benblidia, C. and Khemici, F. (2015) Microalgae Removal from Ghrib Dam (AinDefla, Algeria) Water by Electroflotation Using Stainless Steel Electrodes. Desalination and Water Treatment, 54, 3328-3337. https://doi.org/10.1080/19443994.2014.907749

[140] Al Arni, S., Amous, J. and Ghernaout, D. (2019) On the Perspective of Applying of a New Method for Wastewater Treatment Technology: Modification of the Third Traditional Stage with Two Units, One by Cultivating Microalgae and Another by Solar Vaporization. International Journal of Environmental Sciences \& Natural Resources, 16, Article ID: 555934. https://doi.org/10.19080/IJESNR.2019.16.555934

[141] Ghernaout, D., Alshammari, Y. and Alghamdi, A. (2018) Improving Energetically Operational Procedures in Wastewater Treatment Plants. International Journal of Advanced and Applied Sciences, 5, 64-72. https://doi.org/10.21833/ijaas.2018.09.010

[142] Ghernaout, D. (2019) Brine Recycling: Towards Membrane Processes as the Best Available Technology. Applied Engineering, 3, 71-84.

[143] Ghernaout, D. and El-Wakil, A. (2017) Requiring Reverse Osmosis Membranes Modifications-An Overview. American Journal of Chemical Engineering, 5, 81-88. 
https://doi.org/10.11648/j.ajche.20170504.15

[144] Ghernaout, D. (2017) Reverse Osmosis Process Membranes Modeling-A Historical Overview. Journal of Civil, Construction and Environmental Engineering, 2, 112-122.

[145] Ghernaout, D., El-Wakil, A., Alghamdi, A., Elboughdiri, N. and Mahjoubi, A. (2018) Membrane Post-Synthesis Modifications and How It Came about. International Journal of Advanced and Applied Sciences, 5, 60-64.

https://doi.org/10.21833/ijaas.2018.02.010

[146] Rogers, T.W., Rogers, T.S., Stoner, M.H., Sellgren, K.L., Lynch, B.J., Forbis-Stokes, A.A., Stoner, B.R. and Hawkins, B.T. (2018) A Granular Activated Carbon/Electrochemical Hybrid System for Onsite Treatment and Reuse of Blackwater. Water Research, 144, 553-560. https://doi.org/10.1016/j.watres.2018.07.070

[147] Lei, Q., Zheng, J., Ma, J., Wang, X., Wu, Z. and Wang, Z. (2020) Simultaneous Solid-Liquid Separation and Wastewater Disinfection Using an Electrochemical Dynamic Membrane Filtration System. Environmental Research, 180, Article ID: 108861. https://doi.org/10.1016/j.envres.2019.108861

[148] Anfruns-Estrada, E., Bruguera-Casamada, C., Salvadó, H., Brillas, E., Sirés, I. and Araujo, R.M. (2017) Inactivation of Microbiota from Urban Wastewater by Single and Sequential Electrocoagulation and Electro-Fenton Treatments. Water Research, 126, 450-459. https://doi.org/10.1016/j.watres.2017.09.056 